\title{
A Physical-Chemical Study of the Interference of Ceftriaxone Antibiotic with Copper Chloride Salt
}

\author{
Elsayed M. AbouElleef $\mathbb{D}^{1,2}$ Mowafak M. Mahrouka, ${ }^{1}$ and Sherine E. Salem ${ }^{3}$ \\ ${ }^{1}$ Chemistry Department, Faculty of Arts and Science, Rafha Northern Border University, 91911 Rafha, Saudi Arabia \\ ${ }^{2}$ Basic Science Department, Delta Higher Institute for Engineering and Technology, Mansoura, 35681 Dakhlia, Egypt \\ ${ }^{3}$ Chemistry Department, Faculty of Science, Mansoura University, 35516 Mansoura, Egypt
}

Correspondence should be addressed to Elsayed M. AbouElleef; s.abouelleef@yahoo.com

Received 7 August 2021; Revised 2 October 2021; Accepted 6 October 2021; Published 19 October 2021

Academic Editor: Guillermo Mendoza-Diaz

Copyright ( $) 2021$ Elsayed M. AbouElleef et al. This is an open access article distributed under the Creative Commons Attribution License, which permits unrestricted use, distribution, and reproduction in any medium, provided the original work is properly cited.

\begin{abstract}
The nano- $\mathrm{CuCl}_{2} \cdot 2 \mathrm{H}_{2} \mathrm{O}$ salt was prepared by the ball milling method. The association parameters for bulk and nano-CuCl 2 salts in $\mathrm{H}_{2} \mathrm{O}$ are estimated at different temperatures using the conductivity method by applying the Fuoss-Shedlovsky equation and it was higher for nano- $\mathrm{CuCl}_{2}$ than bulk $\mathrm{CuCl}_{2}$ salt. The interaction between the cation $\left(\mathrm{Cu}^{2+}\right)$ and ligand (ceftriaxone) in $\mathrm{H}_{2} \mathrm{O}$ was determined also by the conductometric method. Two stoichiometric complexes $1 / 2$ and $1 / 1$ (M/L) are estimated and follow the order $K_{\mathrm{f}}(1 / 1)>K_{\mathrm{f}}(1: 2)$ and $\Delta G_{\mathrm{f}}(1 / 1)>\Delta G_{\mathrm{f}}(1 / 2)$ for $(\mathrm{M}: \mathrm{L})$ (in negative values) indicate the favorable of formation of $(1 / 1)$ complex compared to the $(1: 2)$ complex. The Gibbs free energies change was increased in negative signs with increasing the temperature. The antimicrobial activities of CFT, bulk Cu-CFT complex, and nano-Cu-CFT complex were studied on LB agar by the disc diffusion technique against clinical isolates of gram-negative bacteria (Klebsiella pneumonia and Pseudomonas aeruginosa) and Fungi (Candida albicans). It was observed that (CFT) has a higher zone of inhibition and antibacterial activity than that of bulk and nano-Cu-CFT complexes in Klebsiella pneumonia and Pseudomonas aeruginosa (gram-negative bacteria). The nano-Cu-CFT complex showed a higher clear zone of inhibition and antifungal activity against candida than bulk Cu-CFT complex while the absence of the inhibition zone in CFT, so nano-Cu-CFT complex, can be used as an antifungal drug.
\end{abstract}

\section{Introduction}

Nanoparticles (NPs) are a wide class of materials that have a state between bulk and atomic or molecular structures in different shapes of $0 \mathrm{D}, 1 \mathrm{D}, 2 \mathrm{D}$, or $3 \mathrm{D}$ and have a great scientific interest [1-5]. Bulk materials have constant physical properties, with size larger than one micrometer or micron. Nanoparticles can be used for various applications such as drug delivery purposes [6], diagnostics of cancer therapy, gene delivery purposes, chemical and biological sensing [7], gas sensing [8-10], $\mathrm{CO}_{2}$ capturing $[11,12]$, and other related applications [13-17]. Nanoparticles are often used to photocatalytically break down oil into biodegradable compounds, break down volatile organic pollutants in the air, and clean up carbon tetrachloride pollution in spring water $[18,19]$. Nanoparticles (NPs) such as gold, silver, platinum, and palladium showed colors with the variation of shape and size and characteristic properties that can be utilized in bioimaging applications [20]. Another application of nanoparticles is the synthesis of photocatalysis S-doped $\mathrm{TiO}_{2}$ nanoparticles and the study of their photocatalytic, antimicrobial, and antioxidant activities under sunlight illumination [21].

Ceftriaxone [22-25] is an antibiotic that belongs to a category of medicine referred to as cephalosporin antibiotics, and it treats a variety of bacterial infections by stopping the growth of bacteria variety of bacterial infections (e.g., middle ear, lower tract, skin, and urinary tract), meningitis, gonorrhea, pelvic disease, and joint infections. 
Thermodynamics parameters are an important tool for learning about the spontaneity of a given process at a particular temperature $[26,27]$. Determination of the formation constant is fundamental for understanding the behavior of the metal cations in the presence of some chelating agent in a solution and is best explained using thermodynamics. A conductivity technique can be used to estimate the interaction between the metal cations and the chelating agent by estimating the thermodynamics parameters of metal-ligand complex formation [28-32].

It is therefore necessary to study the effect of antibiotic ceftriaxone on the properties of copper chloride salt by determining thermodynamics parameters of interaction between them using conductometric techniques to find the extent of benefit of the antibiotic ceftriaxone.

\section{Experimental}

2.1. Materials and Solutions. The purities and sources of the materials used are presented in Table 1 . The structure of ceftriaxone is shown in Figure 1.

2.2. Apparatus. The conductance measurements are carried out with a conductometer A JENCO, Vision plus-EC3175 conductance instrument, and connecting with Kottermann ultra-thermostat-4130 (a deviation $\pm 0.01 \mathrm{~K}$ ) with a cell constant equal unity. The conductivity bridge was calibrated using standard potassium chloride solutions [33].

The Bruker $D_{8}$ Advance X-ray diffractometer is a powder XRD instrument used to record X-ray diffraction (XRD) patterns of bulk and nanosamples. The Bruker diffractometer with $\mathrm{CuK} \alpha$ anode radiation $(\lambda=0.1542 \mathrm{~nm})$ as a source is operating at $40 \mathrm{kV}$ and $30 \mathrm{~mA}$. The scanning range of over an angular range was between $4^{\circ}$ and $80^{\circ} \mathrm{A}$ at a temperature of $25^{\circ} \mathrm{C}$, and the scan mode was applied with a step width of $0.02^{\circ}$ per step and step time of $0.4 \mathrm{~s}$.

IR instrument of the type Thermo Scientific Nicolet iS10 FTIR spectrometer is operating in the spectral range of 7800 to $400 \mathrm{~cm}^{-1}$ with a resolution of $4 \mathrm{~cm}^{-1}$, midinfrared $\mathrm{KBr}$ beamsplitter 4000 to $400 \mathrm{~cm}^{-1}$.

Solid samples can be prepared by grinding about $5 \mathrm{mg}$ of sample mixed with $100 \mathrm{mg}$ of spectroscopic grade $\mathrm{KBr}$. This powder mixture is then compressed into a pellet using a mechanical press between 4 and 8 ton. $\mathrm{cm}^{-2}$ for 2 minutes in the form of $10 \mathrm{~mm}$ in diameter disks to form a translucent (http://en.wikipedia.org/wiki/Infrared_spectroscopy\%20-\% 20cite_note-Har-2).

\subsection{Procedure}

2.3.1. Preparation of Nanocopper Chloride. The nano$\mathrm{CuCl}_{2} \cdot 2 \mathrm{H}_{2} \mathrm{O}$ salt was prepared by the ball milling method by shaking $\mathrm{CuCl}_{2} \cdot 2 \mathrm{H}_{2} \mathrm{O}$ salt in ball milling apparatus of the type Retsch MM 2000 swing mill at $20225 \mathrm{~Hz}$ at room temperature for one hour. The mill has $10 \mathrm{~cm}^{3}$ stainless steel double-walled tubes. Two balls made from stainless steel of $12 \mathrm{~mm}$ diameter were used.
2.3.2. Preparation of Bulk Cu-CFT Complex and Nano-CuCFT Complex. Bulk Cu-CFT complex and nano-Cu-CFT were prepared according to a traditional method by refluxing $1 \mathrm{mmol}$ of CFT under investigation with $1 \mathrm{mmol}$ of bulk $\mathrm{CuCl}_{2} \cdot 2 \mathrm{H}_{2} \mathrm{O}$ or nano- $\mathrm{CuCl}_{2} \cdot 2 \mathrm{H}_{2} \mathrm{O}$ salts in an ethanolic solution for $2-3 \mathrm{~h}$ close to the boiling point of the solvent. The precipitate was filtered off, washed several times with absolute ethanol, and finally dried in vacuum desiccators over anhydrous calcium chloride.

2.3.3. Conductance Measurements. To calculate the association parameters of $\mathrm{CuCl}_{2} \cdot 2 \mathrm{H}_{2} \mathrm{O}$ solutions, a solution of metal cation $\left(10^{-3} \mathrm{M}, 20 \mathrm{~mL}\right)$ was placed in a double jacket glass conductance cell, and the conductance was measured after each addition of the solvent and stirring at a specific temperature.

To calculate the formation constants between $\mathrm{CuCl}_{2} \cdot 2 \mathrm{H}_{2} \mathrm{O}$ and a ligand (ceftriaxone) in the solvents, a solution of $\mathrm{CuCl}_{2} \cdot 2 \mathrm{H}_{2} \mathrm{O}\left(10^{-3} \mathrm{M}, 20 \mathrm{~mL}\right)$ was placed in a conductance cell, and the conductance was measured. The ligand $\left(10^{-3} \mathrm{M}\right)$ (ceftriaxone) was added step by step to the conductance cell using a micropipette and the conductance was measured after each addition.

2.3.4. Biological Activity. The antimicrobial activities of CFT, bulk Cu-CFT complex, and nano-Cu-CFT complex were studied on LB agar by the disc diffusion technique against clinical isolates of gram-negative bacteria (Klebsiella pneumonia and Pseudomonas aeruginosa) and fungi (Candida albicans).

Sterile filter paper discs $(6 \mathrm{~mm})$ were individually immersed in dimethyl sulfoxide (DMSO) extract of CFT, bulk $\mathrm{Cu}-\mathrm{CFT}$ complex, and nano-Cu-CFT complex, and DMSO was used as control. All the discs were dried, placed on the surface of the test bacterial and fungal, and incubated for 18 to $24 \mathrm{~h}$ at $37^{\circ} \mathrm{C}$. The standard antibiotic used is ceftazidime $(30 \mathrm{mg})$ and finally, the zones of inhibition were examined.

\section{Results and Discussion}

3.1. X-Ray Diffraction (XRD). The X-ray diffraction (XRD) pattern for the bulk and nano- $\mathrm{CuCl}_{2} \cdot 2 \mathrm{H}_{2} \mathrm{O}$ salt is shown in Figure 2. The positions of the main peaks and their relative intensities as measured by powder diffraction are listed in Table 2.

The mean size of nanocrystals was determined from the diffraction peaks corresponding to the most intensive reflections according to the Joint Committee on Powder Diffraction Standards database. Scherrer's equation was used to determine the average crystallite size for nanoparticles from the XRD diffraction pattern measured $[34,35]$ :

$$
d=\frac{K \lambda}{\beta \cos \theta},
$$

where $K$ is Scherrer's constant (about 0.9$), \lambda$ is the wavelength $(\lambda=0.154 \mathrm{~nm}), \beta$ is the line broadening at half the maximum intensity in radians, $\theta$ is the Bragg angle, and $d$ is the averaged dimension of crystallites in nanometers. Groth 
TABLE 1: Sources and purity of the materials.

\begin{tabular}{|c|c|c|c|c|}
\hline Chemical name & CAS reg. no. & Mass fraction & Purification method & Suppliers \\
\hline Ceftriaxone & $104376-79-6$ & 0.990 & Used as received & Sigma-Aldrich \\
\hline Ethanol & $64-17-5$ & 0.995 & Used as received & Sigma-Aldrich \\
\hline $\mathrm{CuCl}_{2} \cdot 2 \mathrm{H}_{2} \mathrm{O}$ & $13464-92-1$ & 0.980 & Used as received & Sigma-Aldrich \\
\hline $\begin{array}{l}\mathrm{H}_{2} \mathrm{O} \\
\text { Mass fraction purity was provided by the suppliers. }\end{array}$ & $7732-18-5$ & $k<0.5 \mu \mathrm{S} \cdot \mathrm{cm}^{-1}$ & Distillation & Our lab \\
\hline
\end{tabular}<smiles>CO/N=C(\C(=O)N[C@@H]1C(=O)N2C(C(=O)O[NH3+])=C(CSc3nc(=O)c(O[NH3+])nn3C)CS[C@H]12)c1csc(N)n1</smiles>

Formula $\mathrm{C}_{18} \mathrm{H}_{16} \mathrm{~N}_{8} \mathrm{Na}_{2} \mathrm{O}_{7} \mathrm{~S}_{3} \cdot 3.5 \mathrm{H}_{2} \mathrm{O}$ Molar mass $598.54 \mathrm{~g} / \mathrm{mol}$

Figure 1: Molecular structure of ceftriaxone antibiotic (CFT). Formula: $\mathrm{C}_{18} \mathrm{H}_{16} \mathrm{~N}_{8} \mathrm{Na}_{2} \mathrm{O}_{7} \mathrm{~S}_{3} \cdot 3.5 \mathrm{H}_{2} \mathrm{O}$. Molar mass: $598.54 \mathrm{~g} / \mathrm{mol}$.

assigned $\mathrm{CuCl}_{2} \cdot 2 \mathrm{H}_{2} \mathrm{O}$ to the bipyramidal class of the orthorhombic crystalline system with the axial ratios $a: b$ : $c=0.9179: 1: 0.4627$. Layer line measurements give the identity distances $a_{0}=7.38 \AA, b_{0}=8.04 \AA, c_{0}=3.72 \AA$. These lead to the ratios $a: b: c=0.918: 1: 0.462$, in good agreement with the crystallographic data [36]. The mean crystal size (nm) of bulk and nano- $\mathrm{CuCl}_{2} \cdot 2 \mathrm{H}_{2} \mathrm{O}$ salts obtained by XRD are mentioned in Table 2 [37].

A little difference was observed between bulk and nanosalts in peaks other than their intensities. Also, it was found that the salt remains in the crystalline form by converting it to nanoparticles. The main difference between the bulk and nanosalt was in the crystal size, as shown in Table 3 .

3.2. Infrared Analysis (IR). Infrared spectra (IR) were used to identify the structure of ceftriaxone (CFT), as shown in Figure 3 , and its complexes with bulk and nano- $\mathrm{CuCl}_{2} \cdot 2 \mathrm{H}_{2} \mathrm{O}$ salts as their functional groups give rise to characteristic bands in terms of both intensity and position (frequency), as shown in Figures 4 and 5.

It was observed from the IR spectra of ceftriaxone (CFT) ligand that amidic $\mathrm{N}-\mathrm{H}$ stretching vibrations mean strong intensity bands occurring at 3440 and $3261 \mathrm{~cm}^{-1}$ are due to $\mathrm{N}-\mathrm{H}$ asymmetric and symmetric stretching, respectively [38]. Amidic $\mathrm{C}=\mathrm{O}$ stretching vibrations mean a strong intensity band identified at $1649 \mathrm{~cm}^{-1}$ is due to $\mathrm{C}=\mathrm{O}$ stretching vibrations [38]. Amidic N-H deformation and C-N stretching mean the strong bands observed at 1608, 1537, and $1500 \mathrm{~cm}^{-1}$ are due to amide $\mathrm{N}-\mathrm{H}$ deformation vibrations $[38,39]$. C-H stretching vibrations mean the weak bands occurring at $2891 \mathrm{~cm}^{-1}$ are assigned to $\mathrm{CH}_{3}$ symmetric stretching. The bands appearing at $2934 \mathrm{~cm}^{-1}$ in the IR spectra are due to $\mathrm{CH}_{3}$ asymmetric stretching vibrations [40]. C-H deformation vibrations mean the weak bands observed at 822,804 , and $730 \mathrm{~cm}^{-1}$ are allotted as C-H outof-plane deformation vibrations and medium-to-weak intensity bands present at 1104 and $1033 \mathrm{~cm}^{-1}$ are allotted as $\mathrm{C}-\mathrm{H}$ in plane deformation vibrations. A strong band occurring at $1399 \mathrm{~cm}^{-1}$ is due to the $-\mathrm{CH}_{2}$ - deformation vibration. Weak bands present at 1243 and $760 \mathrm{~cm}^{-1}$ are due to $\mathrm{CH}_{2}$ wagging and $\mathrm{CH}_{2}$ rocking vibrations, respectively [40]. Lactam $\mathrm{C}=\mathrm{O}$ stretching vibrations mean a strong band observed at $1741 \mathrm{~cm}^{-1}$ in the IR spectrum of ceftriaxone is allotted to be due to $\mathrm{C}=\mathrm{O}$ stretching vibration [41]. C-O-C stretching vibrations mean strong bands present at 1033 and $1243 \mathrm{~cm}^{-1}$ are assigned as C-O-C symmetric and asymmetric stretching vibrations, respectively [41]. C-S stretching vibrations mean weak bands observed at 646 and $616 \mathrm{~cm}^{-1}$ are due to C-S stretching vibrations [42]. C-N stretching vibrations mean the medium band present at $1285 \mathrm{~cm}^{-1}$, weak band at $1243 \mathrm{~cm}^{-1}$, and medium band present at $1185 \mathrm{~cm}^{-1}$ are due to $\mathrm{C}-\mathrm{N}$ stretching vibrations. $\mathrm{C}=\mathrm{C}$ and $\mathrm{C}=\mathrm{N}$ stretching vibrations mean very strong intensity bands present at 1608,1537 , and $1500 \mathrm{~cm}^{-1}$ are assigned to $\mathrm{C}=\mathrm{C}$ and $\mathrm{C}=\mathrm{N}$ stretching vibrations [43]. $\mathrm{O}-\mathrm{H}$ stretching vibrations mean strong intensity bands identified at 3440 and $3261 \mathrm{~cm}^{-1}$ are allotted as O-H stretching vibrations [44]. C-C and $\mathrm{C}-\mathrm{C}-\mathrm{C}$ bending vibrations mean a very weak band occurring at $507 \mathrm{~cm}^{-1}$ in is due to C-C out-of-plane bending vibrations. The weak bands occurring at 646 and $606 \mathrm{~cm}^{-1}$ are due to $\mathrm{C}-\mathrm{C}-\mathrm{C}$ in plane and out of plane deformation vibrations, respectively [45].

In the IR spectra of bulk Cu-CFT complex, as shown in Figure 4, after ceftriaxone coordination to copper ion, the frequencies of the $(\mathrm{C}=\mathrm{O})$ lactam shifted from $1741 \mathrm{~cm}^{-1}$ to higher wavenumber $1775 \mathrm{~cm}^{-1}$, one amidic $(C=O)$ shifted from 1649 to lower wavenumber $1624 \mathrm{~cm}^{-1}$, and also another amidic $(\mathrm{C}=\mathrm{O})$ triazine shifted from 1608 to lower wavenumber $1553 \mathrm{~cm}^{-1}$. There are three functional groups participating in the formation of a complex. The increase in the vibrational frequencies of carbonyl groups can be explained by oxygen of lactam and triazine coordinating to $\mathrm{Cu}(\mathrm{II})$ indicates the formation of a chelate complex $[46,47]$. These intramolecular interactions between oxygen and copper ion result in a more rigid molecular structure around the oxygen and shift of carbonyl $(\mathrm{C}=\mathrm{O})$ vibrational frequencies to higher wavenumbers. The frequency of the symmetric stretching mode $v_{\mathrm{s}}(\mathrm{COO}-)$ shifts from 1391 to $1398 \mathrm{~cm}^{-1}$. These shifts indicate that the carboxylate group (COO), the lactam carbonyl group $(\mathrm{C}=\mathrm{O})$, and the oxo group of the triazine ring are involved in the formation of $[\mathrm{Cu}(\mathrm{CFT})] \cdot 3 \mathrm{H}_{2} \mathrm{O}$. This analysis is in agreement with previous studies where ceftriaxone is described as a polydentate chelating ligand $[46,47]$. The broadband in the $[\mathrm{Cu}(\mathrm{CFT})]$. 

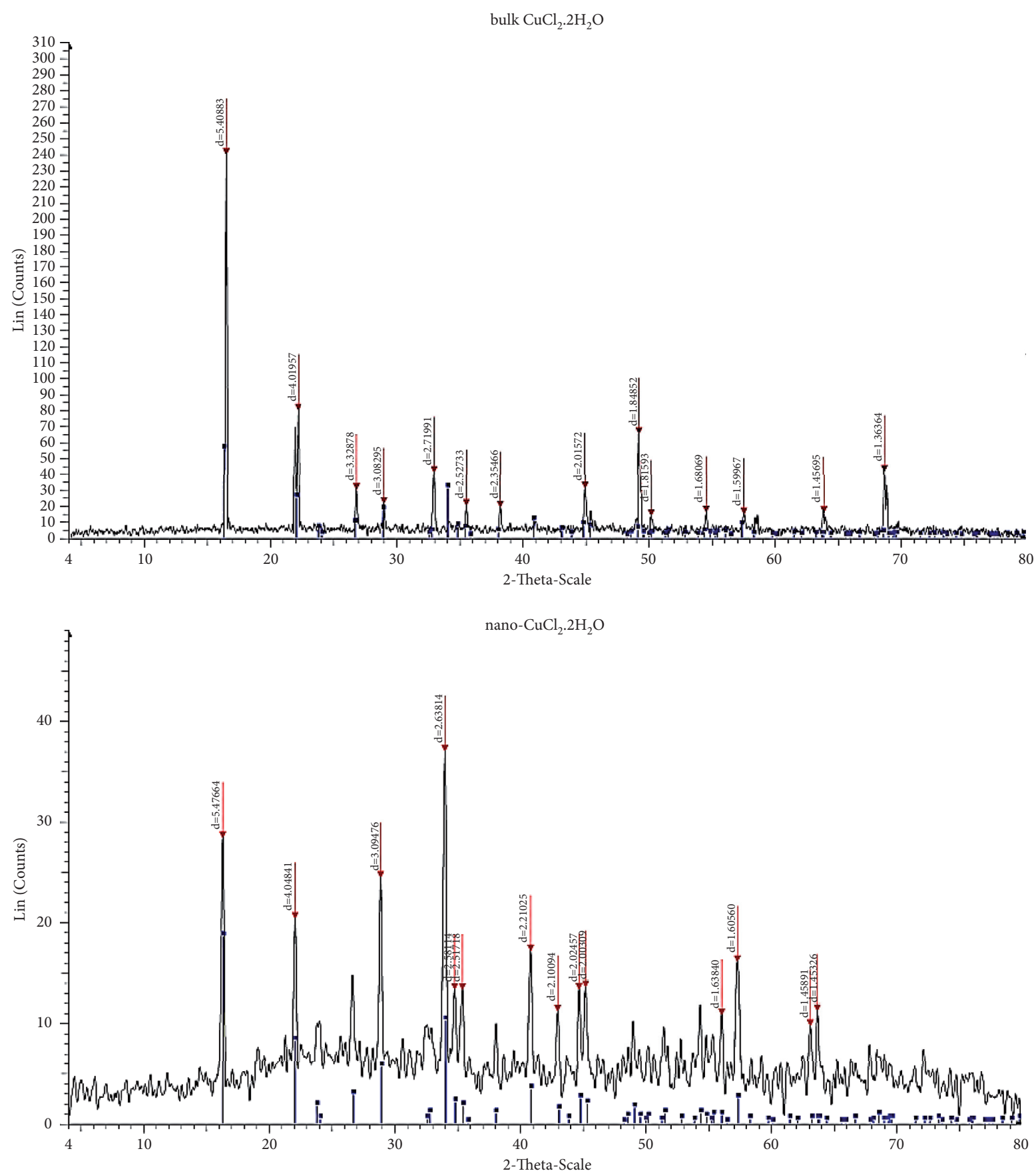

Figure 2: X-Ray diffraction of bulk and nano- $\mathrm{CuCl}_{2} \cdot 2 \mathrm{H}_{2} \mathrm{O}$ salt.

TABLE 2: Intensity (\%) and crystal size (nm) of bulk and nano- $\mathrm{CuCl}_{2} \cdot 2 \mathrm{H}_{2} \mathrm{O}$ salt.

\begin{tabular}{|c|c|c|c|c|c|c|c|c|c|}
\hline \multicolumn{4}{|c|}{ Bulk $\mathrm{CuCl}_{2} 00 \mathrm{~B} 72 \mathrm{H}_{2} \mathrm{O}$ salt } & \multirow[b]{2}{*}{$\begin{array}{c}\text { Crystal } \\
\text { size } \\
(\mathrm{nm})\end{array}$} & \multicolumn{5}{|c|}{ Nano- $\mathrm{CuCl}_{2} \cdot 2 \mathrm{H}_{2} \mathrm{O}$ salt } \\
\hline $\begin{array}{l}\text { Angle (2- } \\
\left.\text { theta }{ }^{\circ}\right)\end{array}$ & $\begin{array}{c}\mathrm{d} \text { value } \\
\text { (angstrom) }\end{array}$ & $\begin{array}{c}\text { Intensity } \\
\text { (count) }\end{array}$ & $\begin{array}{c}\text { Intensity } \\
\%\end{array}$ & & $\begin{array}{c}\text { Angle } \\
\left(2 \text {-theta }{ }^{\circ}\right)\end{array}$ & $\begin{array}{c}\mathrm{d} \text { value } \\
\text { (angstrom) }\end{array}$ & $\begin{array}{c}\text { Intensity } \\
\text { (count) }\end{array}$ & $\begin{array}{c}\text { Intensity } \\
\%\end{array}$ & $\begin{array}{c}\text { Crystal size } \\
\quad(\mathrm{nm})\end{array}$ \\
\hline 16.375 & 5.40883 & 241 & 100 & 158.2 & 16.171 & 5.47654 & 28.5 & 76.8 & 16.171 \\
\hline 22.097 & 4.01957 & 80 & 33.2 & 58.4 & 21.937 & 4.04841 & 20.4 & 55 & 21.937 \\
\hline 26.76 & 3.32876 & 29.9 & 12.4 & 101.5 & 28.825 & 3.09476 & 24.5 & 65.9 & 28.825 \\
\hline 28.938 & 3.08295 & 21.2 & 8.8 & 58.4 & 33.954 & 2.63814 & 37.1 & 100 & 33.954 \\
\hline 32.916 & 2.71891 & 40.8 & 17 & 111.3 & 34.727 & 2.58114 & 13.3 & 35.9 & 34.727 \\
\hline 35.491 & 2.52733 & 19.8 & 8.2 & 52.1 & 35.349 & 2.53715 & 13.3 & 35.8 & 35.349 \\
\hline
\end{tabular}


TABLE 2: Continued.

\begin{tabular}{|c|c|c|c|c|c|c|c|c|c|}
\hline \multicolumn{5}{|c|}{ Bulk $\mathrm{CuCl}_{2} 00 \mathrm{~B} 72 \mathrm{H}_{2} \mathrm{O}$ salt } & \multicolumn{5}{|c|}{ Nano- $\mathrm{CuCl}_{2} \cdot 2 \mathrm{H}_{2} \mathrm{O}$ salt } \\
\hline $\begin{array}{l}\text { Angle (2- } \\
\text { theta }^{\circ} \text { ) }\end{array}$ & $\begin{array}{c}\mathrm{d} \text { value } \\
\text { (angstrom) }\end{array}$ & $\begin{array}{c}\text { Intensity } \\
\text { (count) }\end{array}$ & $\begin{array}{c}\text { Intensity } \\
\%\end{array}$ & $\begin{array}{c}\text { Crystal } \\
\text { size } \\
(\mathrm{nm})\end{array}$ & $\begin{array}{c}\text { Angle } \\
\left(2-\text { theta }^{\circ}\right)\end{array}$ & $\begin{array}{c}\mathrm{d} \text { value } \\
\text { (angstrom) }\end{array}$ & $\begin{array}{c}\text { Intensity } \\
\text { (count) }\end{array}$ & $\begin{array}{c}\text { Intensity } \\
\%\end{array}$ & $\begin{array}{c}\text { Crystal size } \\
(\mathrm{nm})\end{array}$ \\
\hline 38.19 & 2.35466 & 18.9 & 7.8 & 98.1 & 40.793 & 2.21025 & 17.2 & 46.3 & 40.793 \\
\hline 44.933 & 2.01572 & 30.7 & 12.7 & 67.4 & 43.018 & 2.10094 & 11.2 & 30.1 & 43.018 \\
\hline 49.254 & 1.84852 & 65.2 & 27.1 & 132.3 & 44.726 & 2.02457 & 13.3 & 35.9 & 44.726 \\
\hline 50.199 & 1.81593 & 13.5 & 5.6 & 134.6 & 45.234 & 2.00303 & 13.6 & 36.5 & 45.234 \\
\hline 54.558 & 1.68069 & 15.8 & 6.6 & 3 & 56.088 & 1.6384 & 10.8 & 29.1 & 56.088 \\
\hline 57.572 & 1.59967 & 14.6 & 6.1 & 107.9 & 57.343 & 1.6055 & 16.1 & 43.4 & 57.343 \\
\hline 63.915 & 1.45535 & 15.4 & 6.4 & 140.7 & 63.208 & 1.46991 & 9.72 & 26.2 & 63.208 \\
\hline 68.788 & 1.36364 & 41.6 & 17.3 & & & & & & \\
\hline
\end{tabular}

TABle 3: Mean crystal size (nm) of bulk and nano- $\mathrm{CuCl}_{2} \cdot 2 \mathrm{H}_{2} \mathrm{O}$ salts.

\begin{tabular}{lr}
\hline Sample & Crystal size $d_{\text {XRD }}($ nm $)$ \\
\hline Bulk $\mathrm{CuCl}_{2} \cdot 2 \mathrm{H}_{2} \mathrm{O}$ & 94.146 \\
Nano- $\mathrm{CuCl}_{2} \cdot 2 \mathrm{H}_{2} \mathrm{O}$ & 43.98 \\
\hline
\end{tabular}

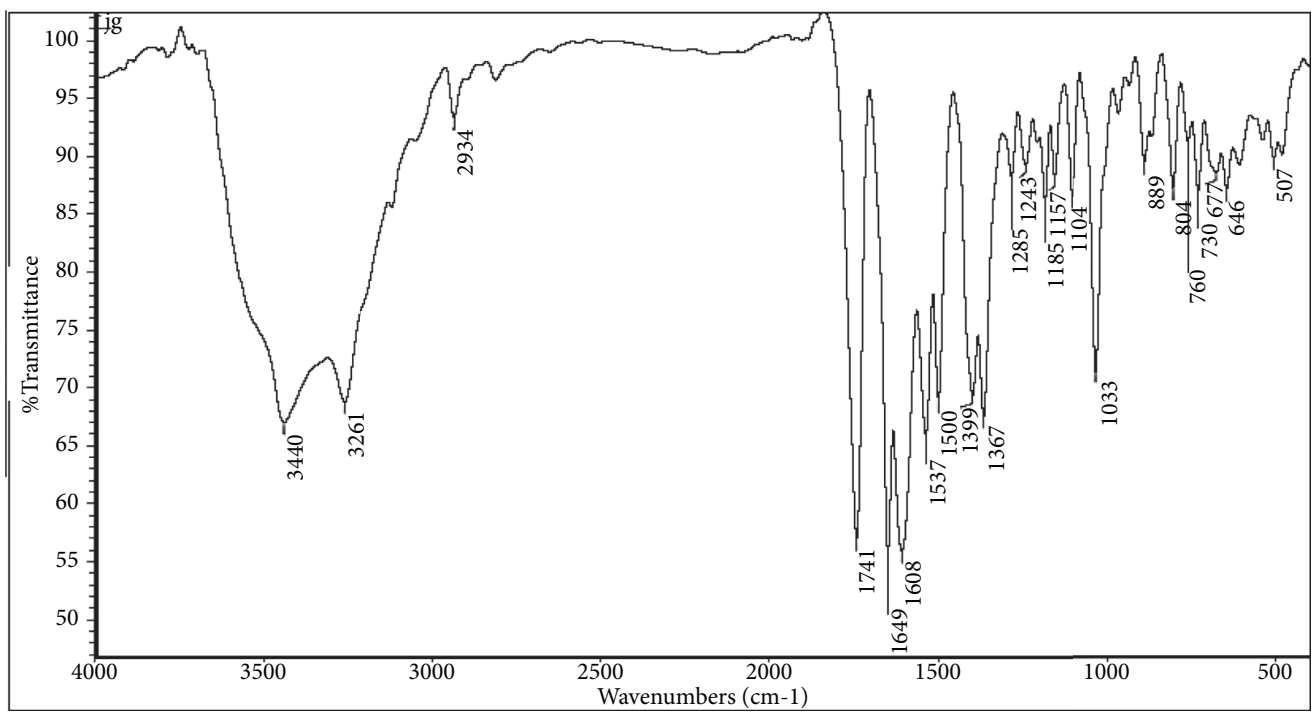

FIgURE 3: IR spectra of ceftriaxone (CFT).

$3 \mathrm{H}_{2} \mathrm{O}$ spectrum at $1624 \mathrm{~cm}^{-1}$ has a high intensity and a low resolution due to the overlap of several vibrational modes, including $\quad v(\mathrm{C}=\mathrm{O})$-amide, $\quad v(\mathrm{C}=\mathrm{O})$-triazine, $v_{\text {as }}(\mathrm{COO}-)$, $v(\mathrm{C}=\mathrm{C})$, and $\nu(\mathrm{C}=\mathrm{N})$. A new band appearing at the frequency $468 \mathrm{~cm}^{-1}$ in the complex that is absent in the free ligand is due to $v(\mathrm{Cu}-\mathrm{N})$ stretching vibration also giving strong evidence for the coordination of tertiary nitrogen atom with copper ion [47].

Also, the IR spectra of nano-Cu-CFT complex asym. $\left(\mathrm{NH}_{2}\right)$ shifted from 3440 to lower wavenumber $3427 \mathrm{~cm}^{-1}$, carboxylic $(-\mathrm{OH})$ group appeared at wavenumber $2924 \mathrm{~cm}^{-1}$, carboxylic $(\mathrm{C}=\mathrm{O})$ appeared at wavenumber $1742 \mathrm{~cm}^{-1}$, one amidic $(\mathrm{C}=\mathrm{O})$ shifted from 1649 to lower wavenumber $1638 \mathrm{~cm}^{-1}$ and also another amidic $(\mathrm{C}=\mathrm{O})$ shifted from 1608 to lower wavenumber $1553 \mathrm{~cm}^{-1}$, as in Figure 5. This indicates the formation of a complex between $\mathrm{CuCl}_{2} \cdot 2 \mathrm{H}_{2} \mathrm{O}$ salt and CFT antibiotic.

\subsection{Conductometric Measurements}

3.3.1. Calculation of Association Parameters for Bulk and Nano-CuCl${ }_{2} \cdot \mathrm{H}_{2} \mathrm{O}$ Salts in Distillate $\mathrm{H}_{2} \mathrm{O}$. The specific conductance values $\left(K_{\mathrm{s}}\right)$ of different concentrations of bulk and nano- $\mathrm{CuCl}_{2} \cdot 2 \mathrm{H}_{2} \mathrm{O}$ salt in distillate $\mathrm{H}_{2} \mathrm{O}$ were measured experimentally in absence of (CFT) at different temperatures $(288.15,293.15,298.15$, and $303.15 \mathrm{~K})$. The molar conductance $\left(\Lambda_{\mathrm{m}}\right)$ values were calculated [48-50] using

$$
\Lambda_{\mathrm{m}}=\frac{\left(K_{s}-K_{\mathrm{solv}}\right) \times 1000}{C}
$$

where $K_{\mathrm{s}}$ and $K_{\text {solv }}$ are the specific conductance of the solution and the solvent (distillate $\mathrm{H}_{2} \mathrm{O}$ ), respectively, and $\mathrm{C}$ is the concentration of the bulk and nano- $\mathrm{CuCl}_{2} \cdot 2 \mathrm{H}_{2} \mathrm{O}$ solutions. 


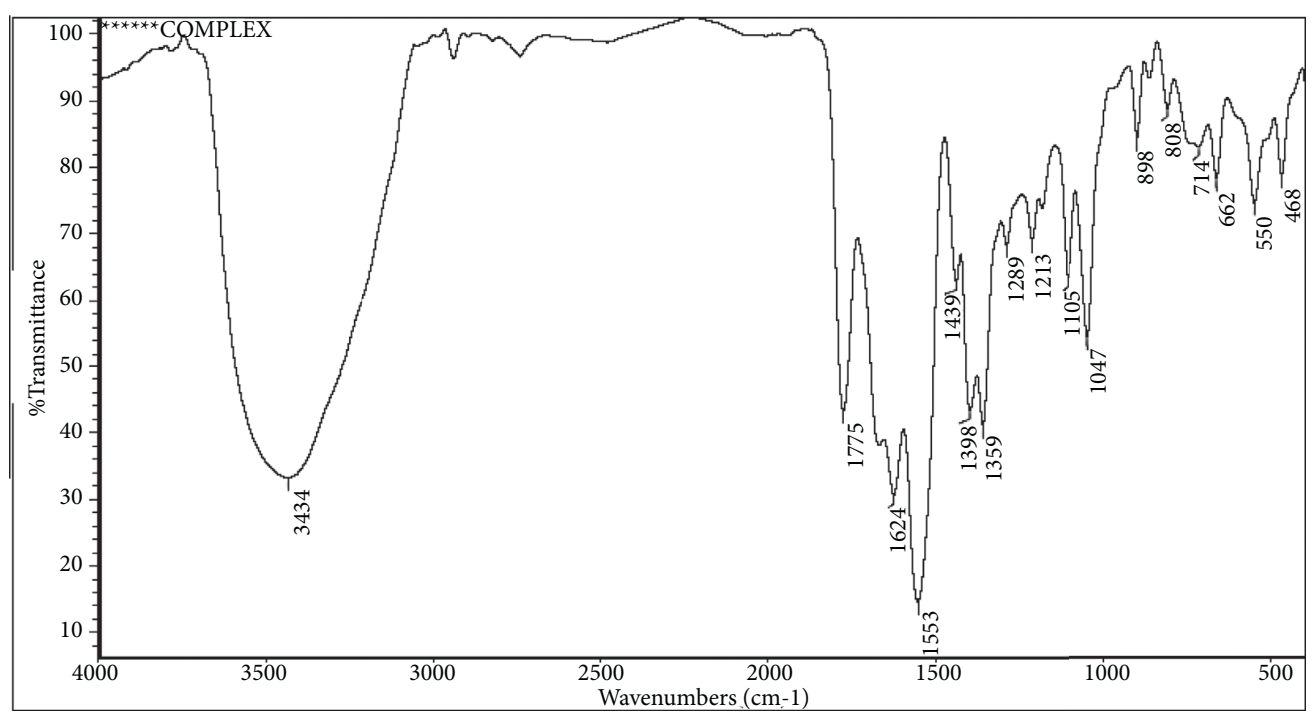

FIgURE 4: IR spectra of bulk Cu-CFT complex.

The experimental data for conductance measurements were analyzed using Fuoss-Shedlovsky extrapolation techniques [51-53] which follow equations (3)-(12):

$$
\frac{1}{\Lambda S_{(Z)}}=\frac{1}{\Lambda_{o}}+\left(\frac{K_{A}}{\Lambda_{o}^{2}}\right)\left(C \Lambda \gamma_{ \pm}^{2} S_{(Z)}\right)
$$

The results obey the Fuoss-Shedlovsky equation and can be applied to obtain the value of limiting molar conductivity $\left(\Lambda_{\mathrm{o}}\right)$ and association constant $\left(K_{\mathrm{A}}\right)$ by plotting a graph between $1 / \Lambda S(z)$ and $\left(C \Lambda S(z) \gamma_{ \pm}^{2}\right)$, which is presented in Figure 6 , giving straight line with intercept $\left(1 / \Lambda_{\mathrm{o}}\right)$ and slope $\left(K_{\mathrm{A}} / \Lambda_{\mathrm{o}}^{2}\right)$ :

$$
\begin{aligned}
S_{(Z)} & =1+Z+\frac{Z^{2}}{2}+\frac{Z^{3}}{2}+\ldots, \\
Z & =\frac{S(\Lambda C)^{1 / 2}}{\Lambda_{0}^{3 / 2}}, \\
S & =a \Lambda_{0}+b, \\
a & =\frac{8.2 \times 10^{5}}{(\varepsilon T)^{3 / 2}}, \\
b & =\frac{82.4}{\eta(\varepsilon T)^{1 / 2}}, \\
(\alpha) & =\frac{\Lambda S_{(Z)}}{\Lambda_{0}}, \\
\log \gamma_{ \pm} & =\frac{-A(\alpha C)^{1 / 2}}{\left[1+B r^{o}(\alpha C)^{1 / 2}\right]}, \\
A & =1.824 \times 10^{6}(\varepsilon T)^{-3 / 2}, \\
B & =50.29 \times 10^{8}(\varepsilon T)^{-1 / 2},
\end{aligned}
$$

$$
K_{A}=\frac{C_{\left[M X_{n}\right]} \cdot \gamma_{\left[M X_{n}\right]}}{C_{M^{n+}} \cdot \gamma_{M^{n+}} \cdot C_{X^{-}}^{n} \cdot \gamma_{X^{-}}^{n}},
$$

where $(S)$ is the Onsager slope; $(\varepsilon)$ is the dielectric constant of the solvent, ; $\left(\eta_{\mathrm{o}}\right)$ is the viscosity of the solvent; $(T)$ is the temperature; $(\alpha)$ is the degree of dissociation; $\left(\gamma_{ \pm}\right)$is the mean activity coefficients; $\left(z^{-}, z^{+}\right)$are the charges of ions in solutions; $(A, B)$ are the Debye-Hückel constant; $\left(r^{\circ}\right)$ is the solvated radius; and $\left(K_{\mathrm{A}}\right)$ is the association constant.

The dissociation constant $\left(K_{\mathrm{D}}\right)$ is calculated by the following equation:

$$
K_{D}=\frac{1}{K_{A}} .
$$

The Walden product $\left(\Lambda_{\mathrm{o}} \eta_{\mathrm{o}}\right)$ values were calculated from the values of limiting molar conductance $\left(\Lambda_{\mathrm{o}}\right)$ [54]:

$$
\text { Walden product }=\Lambda_{o} \eta_{o}
$$

The triple ion association constant $K_{3}$ can be calculated from

$$
\frac{\Lambda C^{1 / 2}}{\left(1-\left(\Lambda / \Lambda_{o}\right)\right)^{1 / 2}}=\frac{\Lambda_{o}}{\left(K_{A}\right)^{1 / 2}}+\frac{\lambda_{3}^{o} C}{K_{3}\left(K_{A}\right)^{1 / 2}}\left(1-\frac{\Lambda}{\Lambda_{o}}\right) .
$$

The values of free energy of association $\left(\Delta G_{\mathrm{A}}\right)$ of bulk and nano- $\mathrm{CuCl}_{2} \cdot 2 \mathrm{H}_{2} \mathrm{O}$ salt in $\mathrm{H}_{2} \mathrm{O}$ at different temperatures of $288.15,293.15,298.15$, and $303.15 \mathrm{~K}$ were calculated from the association constant $K_{\mathrm{A}}$ values [55] by using

$$
\Delta G_{A}=-2.303 R T \log K_{A} .
$$

The activation energy of the transfer process can be estimated depending on the relation between conductance of ion, ion mobility, and temperature degree, as in the Arrhenius equation:

$$
\Lambda_{o}=A e^{-E_{a} / R T}
$$




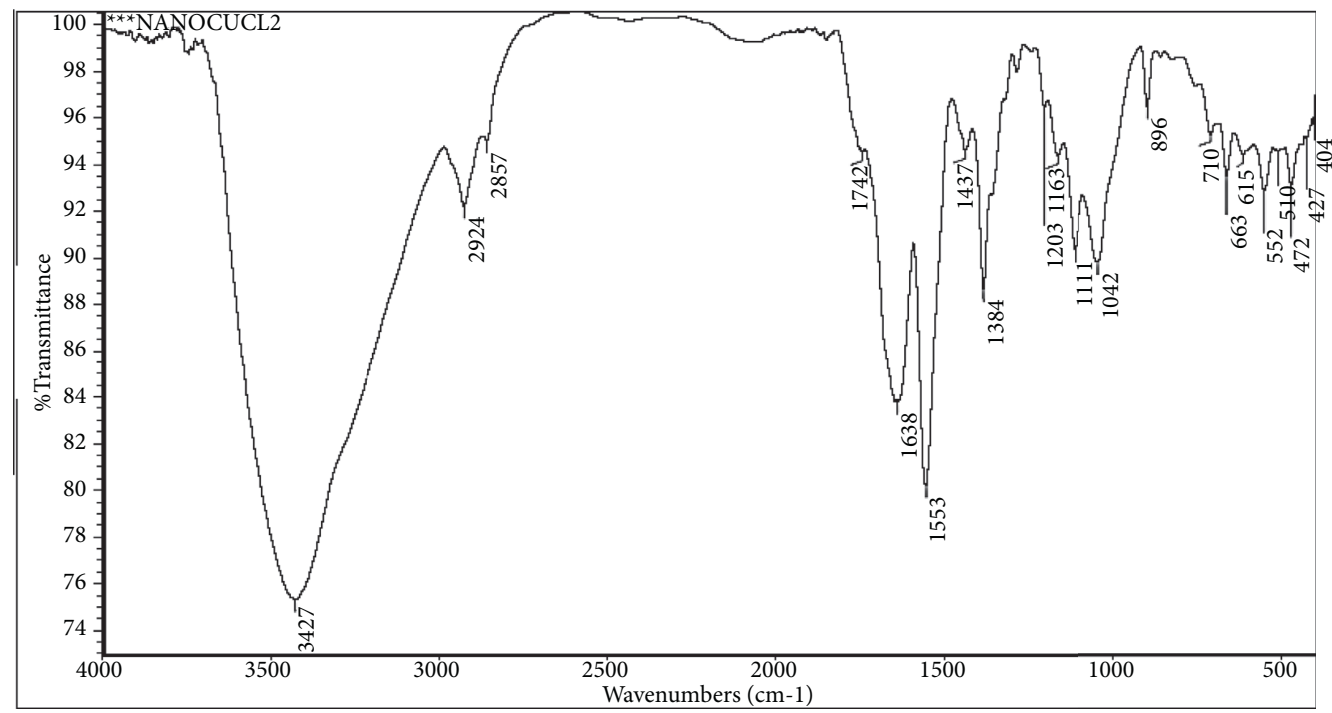

FIGURE 5: IR spectra of nano-Cu-CFT complex.

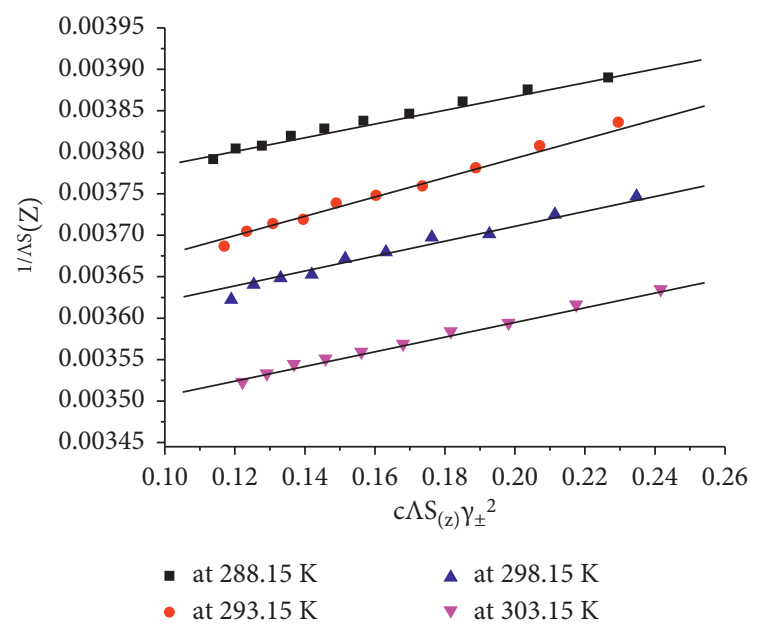

(a)

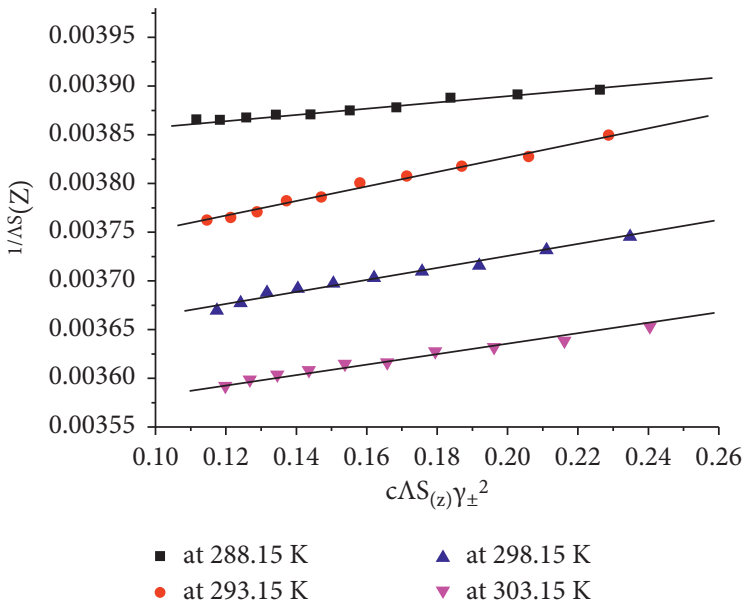

(b)

Figure 6: Variation of the molar conductance, $1 / \Lambda S_{(z)}$ with $C \Lambda \gamma_{ \pm}^{2} S_{(z)}$ for (a) bulk $\mathrm{CuCl}_{2} \cdot 2 \mathrm{H}_{2} \mathrm{O}$ and (b) nano- $\mathrm{CuCl}_{2} \cdot 2 \mathrm{H}_{2} \mathrm{O}$ in distillate $\mathrm{H}_{2} \mathrm{O}$ at $(288.15,293.15,298.15$, and 303.15) K.

where $\mathrm{A}$ is the frequency factor and $E_{\mathrm{a}}$ Arrhenius activation energy of the transport process.

$$
\log \Lambda_{o}=\log A-\frac{E_{a}}{2.303 R T} .
$$

By plotting $\log \Lambda_{\mathrm{o}}$ versus $1 / T$, as shown in Figure 7 , the activation energy of transfer processes values can be calculated from the slope [56].

The calculated values of $\Lambda_{\mathrm{o}}, S_{(Z)}, \alpha, \gamma_{ \pm}, K_{\mathrm{A}}, K_{\mathrm{D}}$, and $K_{3}$ for the solutions of bulk and nano- $\mathrm{CuCl}_{2} \cdot 2 \mathrm{H}_{2} \mathrm{O}$ salt with distillate $\mathrm{H}_{2} \mathrm{O}$ at different temperatures of 288.15, 293.15, 298.15 , and $303.15 \mathrm{~K}$ are calculated and reported in Tables 4 and 5 .

Table 4 shows that the limiting molar conductivity $\left(\Lambda_{\mathrm{o}}\right)$ increases with increasing temperature due to the increase in mobility of ions and increasing kinetic energy which increases the separation among the oppositely charged ions while the Walden product $\left(\Lambda_{\mathrm{o}} \eta\right)$ decreases with increasing the temperature due to the decrease in viscosity; also, the association constant $\left(K_{\mathrm{A}}\right)$ decreases with increasing the temperature due to the decrease in the association of ions and the increase in mobility of ions; and similarly, the triple ion association constant $\left(\mathrm{K}_{3}\right)$ decreases with increasing the temperature due to the decrease for the same reason.

Table 5 shows the same trend, that is, the limiting molar conductivity $\left(\Lambda_{\mathrm{o}}\right)$ increases with increasing the temperature while the Walden product $\left(\Lambda_{\mathrm{o}} \eta\right)$ decreases with increasing the temperature; also association constant $\left(K_{\mathrm{A}}\right)$ decreases with increasing the temperature; and similarly, the triple ion association constant $\left(K_{3}\right)$ decreases with increasing the temperature. 


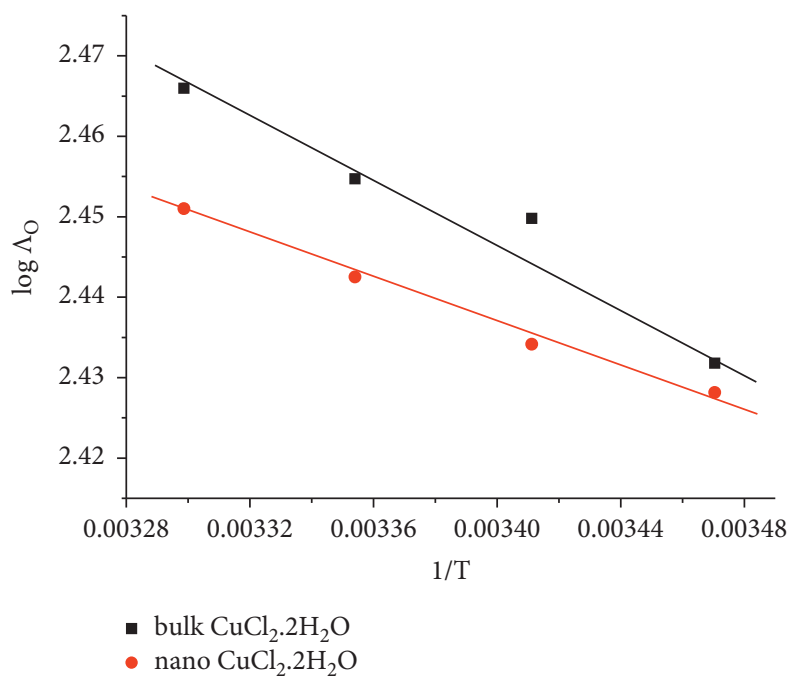

Figure 7: Variation of $\log \Lambda_{\mathrm{o}}$ with $\mathrm{l} / \mathrm{T}\left(\mathrm{K}^{-1}\right)$ of for bulk and nano- $\mathrm{CuCl}_{2} \cdot 2 \mathrm{H}_{2} \mathrm{O}$ in $\mathrm{H}_{2} \mathrm{O}$.

TABLE 4: Different association parameters (limiting molar conductance $\left(\Lambda_{\mathrm{o}}\right)$, Fuoss-Shedlovsky parameter $S_{(z)}$, degree of dissociation $(\alpha)$, activity coefficient $\left(\gamma_{ \pm}\right)$, association constant $\left(K_{\mathrm{A}}\right)$, dissociation constant $\left(K_{\mathrm{D}}\right)$, triple ion association constant $\left.\left(K_{3}\right)\right)$ for bulk $\mathrm{CuCl}_{2} \cdot 2 \mathrm{H}_{2} \mathrm{O}$ in distillate $\mathrm{H}_{2} \mathrm{O}$ at $288.15,293.15,298.15$, and $303.15 \mathrm{~K}$ in absence of CFT.

\begin{tabular}{cccccccc}
\hline$T(\mathrm{~K})$ & $\Lambda_{\mathrm{o}} S \cdot \mathrm{cm}^{2} \cdot \mathrm{mol}^{-1}$ & $\Lambda_{\mathrm{o}} \eta \mathrm{S} \cdot \mathrm{cm}^{2} \cdot \mathrm{MPa} \cdot \mathrm{s} \cdot \mathrm{mol}^{-1}$ & $\alpha$ & $\gamma_{ \pm}$ & $K_{\mathrm{A}} \mathrm{dm}^{3} \cdot \mathrm{mol}^{-1}$ & $10^{-3} K_{\mathrm{D}} \mathrm{mol} \cdot \mathrm{dm}^{-3}$ & $10^{5} K_{3}\left(\mathrm{dm} \cdot \mathrm{mol}^{-1}\right)^{2}$ \\
\hline 288.15 & 270.00 & 307.43 & 0.9806 & 0.9022 & 99.74 & 0.0100 & 1.322 \\
293.15 & 281.69 & 282.14 & 0.9668 & 0.9013 & 93.39 & 0.0107 & 1.273 \\
298.15 & 284.90 & 254.16 & 0.9755 & 0.9005 & 82.79 & 0.0120 & 1.190 \\
303.15 & 292.39 & 233.09 & 0.9912 & 0.8995 & 78.32 & 0.0127 & 1.154 \\
\hline
\end{tabular}

TABLE 5: Different association parameters (limiting molar conductance $\left(\Lambda_{0}\right)$, Fuoss-Shedlovsky parameter $S_{(z)}$, degree of dissociation $(\alpha)$, activity coefficient $\left(\gamma_{ \pm}\right)$, association constant $\left(K_{\mathrm{A}}\right)$, dissociation constant $\left(K_{\mathrm{D}}\right)$, triple ion association constant $\left.\left(K_{3}\right)\right)$ for nano-CuCl $2 \cdot 2 \mathrm{H}_{2} \mathrm{O}$ in distillate $\mathrm{H}_{2} \mathrm{O}$ at $288.15,293.15,298.15$, and $303.15 \mathrm{~K}$ in the absence of CFT.

\begin{tabular}{lccccccc}
\hline$T(\mathrm{~K})$ & $\Lambda_{\mathrm{o}} \mathrm{S} \cdot \mathrm{cm}^{2} \cdot \mathrm{mol}^{-1}$ & $\Lambda_{\mathrm{o}} \eta \mathrm{S} \cdot \mathrm{cm}^{2} \cdot \mathrm{MPa} \cdot \mathrm{s} \cdot \mathrm{mol}^{-1}$ & $\alpha$ & $\gamma_{ \pm}$ & $K_{\mathrm{A}} \mathrm{dm}^{3} \cdot \mathrm{mol}^{-1}$ & $10^{-3} K_{\mathrm{D}} \mathrm{mol} \mathrm{dm}^{-3}$ & $10^{5} K_{3}\left(\mathrm{dm}^{3} \cdot \mathrm{mol}^{-1}\right)^{2}$ \\
\hline 288.15 & 266.21 & 302.58 & 0.9754 & 0.9022 & 60.60 & 0.0165 & 0.9949 \\
293.15 & 271.73 & 282.14 & 0.9013 & 0.9013 & 56.35 & 0.0177 & 0.9546 \\
298.15 & 277.00 & 247.11 & 0.9873 & 0.9005 & 46.16 & 0.0216 & 0.8499 \\
303.15 & 282.48 & 225.19 & 0.9874 & 0.8995 & 34.47 & 0.0290 & 0.0714 \\
\hline
\end{tabular}

The enthalpy $\left(\Delta H_{A}\right)$ for bulk and nano- $\mathrm{CuCl}_{2} \cdot 2 \mathrm{H}_{2} \mathrm{O}$ salts with distillate $\mathrm{H}_{2} \mathrm{O}$ at different temperatures were calculated by using Van 't Hoff equation:

$$
\log K=-\frac{\Delta H}{2.303 R}\left(\frac{1}{T}\right)+\text { constant. }
$$

By drawing the relation between $\log K_{\mathrm{A}}$ and $1 / \mathrm{T}, \Delta H_{\mathrm{A}}$ can be calculated from the slope of each line which equals $\left(-\Delta H_{\mathrm{A}} / 2.303 \mathrm{R}\right)$, as shown in Figure 8 . The entropy $\left(\Delta S_{\mathrm{A}}\right)$ for bulk and nano- $\mathrm{CuCl}_{2} \cdot 2 \mathrm{H}_{2} \mathrm{O}$ salts were calculated by using

$$
\Delta G_{A}=\Delta H_{A}-T \Delta S_{A},
$$

where $(S)$ is the entropy of the system. The calculated values of $\left(\Delta H_{\mathrm{A}}\right)$ and $\left(\Delta S_{\mathrm{A}}\right)$ for bulk and nano- $\mathrm{CuCl}_{2} \cdot 2 \mathrm{H}_{2} \mathrm{O}$ salts are presented in Table 6. It is obvious that the limiting molar conductance $\left(\Lambda_{\mathrm{o}}\right)$ increased as the temperature increased while the dissociation degree decreased as the temperature increased indicating a higher solvation process. The values of the association constant $\left(K_{\mathrm{A}}\right)$ and the triple ion association constant $\left(K_{3}\right)$ were decreased by increasing the temperature. Gibbs free energies change of association $\left(\Delta G_{\mathrm{A}}\right)$ was decreased with negative signs by increasing the temperature indicating that association is favored with lowering of dielectric constant of solvent mixture. The decrease in the values of activity coefficient, limiting molar conductance, association constant, Gibbs free energy change of association, and Walden product for nano- $\mathrm{CuCl}_{2} \cdot 2 \mathrm{H}_{2} \mathrm{O}$ in comparison to bulk $\mathrm{CuCl}_{2} \cdot 2 \mathrm{H}_{2} \mathrm{O}$ indicates that the association of nano- $\mathrm{CuCl}_{2} \cdot 2 \mathrm{H}_{2} \mathrm{O}$ is greater than bulk $\mathrm{CuCl}_{2} \cdot 2 \mathrm{H}_{2} \mathrm{O}$ salt, due to the high surface to volume ratio of nanoparticles which leads to a greater ability for ion-pair formation.

3.3.2. Calculation of Formation Constants for Bulk and Nano-Cu-CFT Complexes in $\mathrm{H}_{2} \mathrm{O}$ at Different Temperatures. Different lines were obtained with breaks indicating the formation of $(1: 2)$ and $(1: 1)(M: L)$ stoichiometric 


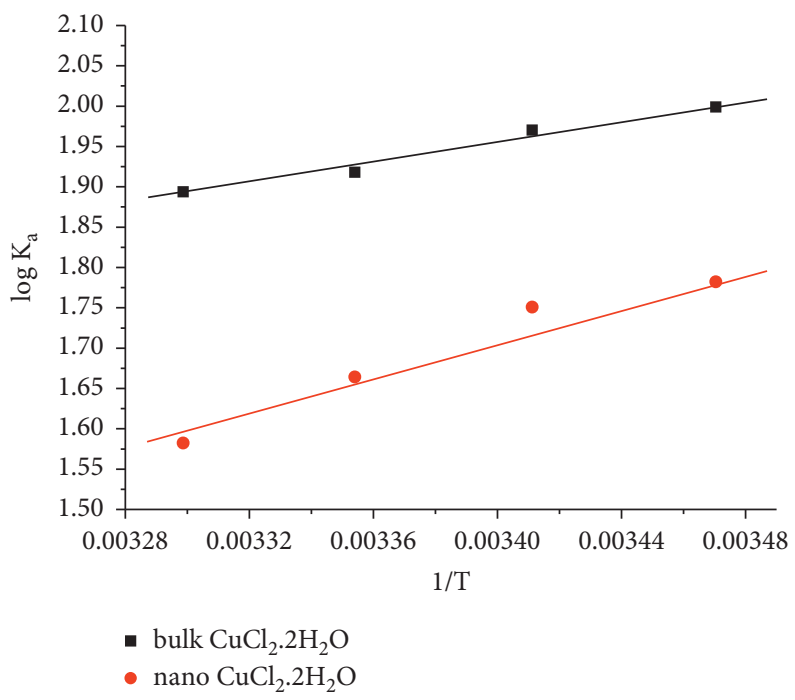

FIgure 8: Variation of $\log K_{\mathrm{a}}$ with $\mathrm{l} / \mathrm{T}\left(\mathrm{K}^{-1}\right)$ of for bulk and nano- $\mathrm{CuCl}_{2} \cdot 2 \mathrm{H}_{2} \mathrm{O}$ in distillate $\mathrm{H}_{2} \mathrm{O}$ at $288.15,293.15,298.15$, and 303.15 K.

TABle 6: Gibbs free energy of association $\left(\Delta G_{\mathrm{A}}\right)$, enthalpy change $\left(\Delta H_{\mathrm{A}}\right)$, and entropy change $\left(\Delta S_{\mathrm{A}}\right)$ for bulk and nano-CuCl${ }_{2} \cdot 2 \mathrm{H}_{2} \mathrm{O}$ in distillate $\mathrm{H}_{2} \mathrm{O}$ at different temperatures.

\begin{tabular}{|c|c|c|c|c|c|c|c|c|}
\hline \multirow{2}{*}{$\mathrm{T}(\mathrm{K})$} & \multicolumn{2}{|c|}{$\Delta G_{\mathrm{A}}\left(\mathrm{kJ} \mathrm{mol}{ }^{-1}\right)$} & \multicolumn{2}{|c|}{$\Delta H_{\mathrm{A}}\left(\mathrm{kJ} \mathrm{mol}{ }^{-1}\right)$} & \multicolumn{2}{|c|}{$E_{\mathrm{A}}\left(\mathrm{kJ} \mathrm{mol}{ }^{-1}\right)$} & \multicolumn{2}{|c|}{$\Delta S_{\mathrm{A}}\left(\mathrm{kJ} \mathrm{mol}{ }^{-1} \mathrm{~K}^{-1}\right)$} \\
\hline & Bulk & Nano & Bulk & Nano & Bulk & Nano & Bulk & Nano \\
\hline 288.15 & -11.028 & -9.322 & & & & & -0.0496 & -0.0904 \\
\hline 293.15 & -11.059 & -9.828 & -12.928 & -22.918 & 3.60 & 3.72 & -0.0487 & -0.0842 \\
\hline 298.15 & -10.949 & -9.501 & & & & & -0.0477 & -0.0824 \\
\hline 303.15 & -10.993 & -8.924 & & & & & -0.0468 & -0.0807 \\
\hline
\end{tabular}

complexes [57] on drawing the molar conductance $\left(\Lambda_{\mathrm{m}}\right)$ for bulk and nano-Cu-CFT complexes at different temperatures versus the molar ratio of metal to ligand $[M] /[L]$ concentrations, as shown in Figure 9.

The formation constants $\left(K_{\mathrm{f}}\right)$ for bulk and nano-Cu-CFT complexes were calculated for each type of complexes $(1: 2)$ and $(1: 1)(\mathrm{M}: \mathrm{L})$ by using

$$
\begin{array}{r}
M^{2+}+L \leftrightarrow M L^{2+}, \\
K_{\mathrm{f}}=\frac{\left[M L^{2+}\right]}{\left[M^{2+}\right][L]}=\frac{\Lambda_{M-} \Lambda_{\mathrm{obs}}}{\left(\Lambda_{\mathrm{obs}-} \Lambda_{M L}\right)[L]}, \\
{[L]=[L]_{t}-\left\{[\mathrm{M}]_{\mathrm{t}} \frac{\Lambda_{\mathrm{M}-} \Lambda_{\mathrm{obs}}}{\left(\Lambda_{\mathrm{M}-} \Lambda_{\mathrm{ML}}\right)}\right\},}
\end{array}
$$

where $\Lambda_{\mathrm{m}}$ is the limiting molar conductance of the bulk and nano- $\mathrm{CuCl}_{2} \cdot 2 \mathrm{H}_{2} \mathrm{O}$ alone, $\Lambda_{\mathrm{obs}}$ is the molar conductance of solution during titration, $\Lambda_{\mathrm{ML}}$ is the molar conductance of the complex, and $[L]$ is the CFT concentration.

The Gibbs free energies changes of formation $\left(\Delta G_{f}\right)$ for each stoichiometric complex were calculated [4] by using

$$
\Delta G_{\mathrm{f}}=-2.303 R T \log K_{\mathrm{f}} .
$$

The obtained values $\left(K_{\mathrm{f}}\right)$ for bulk and nano-Cu-CFT complexes and their calculated $\Delta G_{\mathrm{f}}$ values are presented in Tables 7 and 8 .
By drawing the relation between $\log K_{\mathrm{f}}$ and $1 / T$, different lines were obtained indicating the formation of $(1: 2)$ and $(1: 1)(M: L)$ stoichiometric complexes, as shown in Figure 10 .

From the relation between $\log K_{\mathrm{f}}$ and $1 / T, \Delta H_{\mathrm{f}}$ can be calculated for each type of complexes, from the slope of each line which equals $\left(-\Delta H_{\mathrm{f}} / 2.303 \mathrm{R}\right)$. The entropy $\left(\Delta S_{\mathrm{f}}\right)$ for bulk and nano-Cu-CFT complexes was calculated for each type of complexes $(1: 2)$ and $(1: 1)(M: L)$ by using

$$
\Delta G_{\mathrm{f}}=\Delta H_{\mathrm{f}}-T \Delta S_{\mathrm{f}} .
$$

The calculated values of $\left(\Delta H_{\mathrm{f}}\right)$ and $\left(\Delta S_{\mathrm{f}}\right)$ for bulk and nano-Cu-CFT complexes are presented in Tables 9 and 10.

It was observed that inflections at $(1: 2) \mathrm{M} / \mathrm{L}$ proportion and $(1: 1) M / L$ indicating the formation of both stoichiometric complexes in the solutions. These types of stoichiometric complexes are formed as a result of the interaction of bulk or nano- $\mathrm{CuCl}_{2}$ with CFT in distillate $\mathrm{H}_{2} \mathrm{O}$ at different temperatures. The complex formation parameters for $(1: 1)$ complexes are greater than those of $(1: 2)$ complexes indicating more favorable complexes. Also, the complex formation parameters $\left(K_{\mathrm{f}}, \Delta G_{\mathrm{f}}\right)$ increased by increasing temperatures due to an increase in the kinetic energies. This trend was supported by entropies data which are greater for $(1: 1) M / L$ complexes than $(1: 2) M / L$ complexes. 


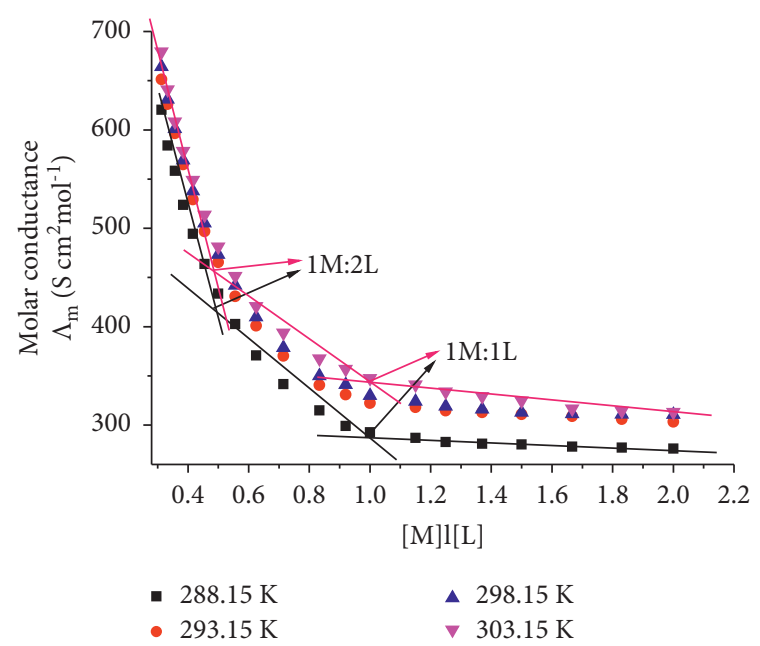

(a)

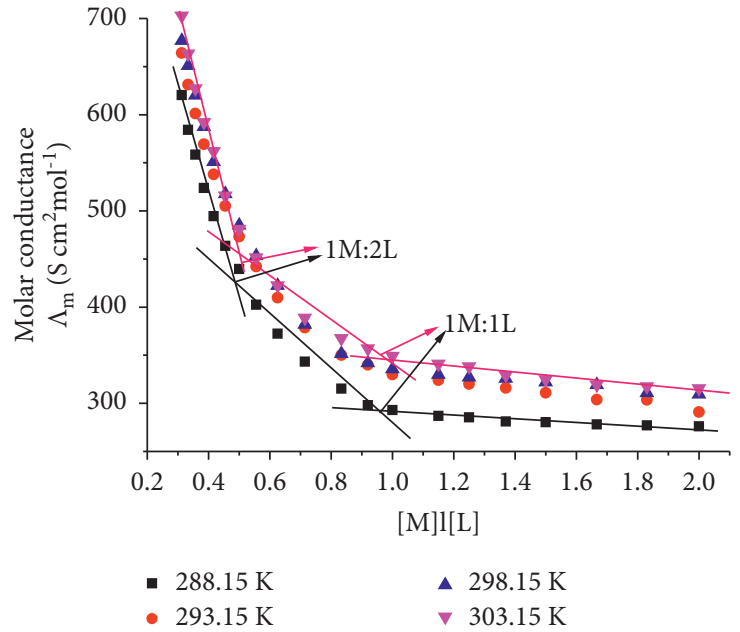

(b)

Figure 9: The relation between $\Lambda_{\mathrm{m}}$ and the $[\mathrm{M}] /[\mathrm{L}]$ molar ratio for (a) bulk Cu-CFT complex and (b) nano-Cu-CFT complex in distillate $\mathrm{H}_{2} \mathrm{O}$ at different temperatures.

TABLE 7: Limiting molar conductance $\left(\Lambda_{\mathrm{o}}\right)$ and formation constant $\left(K_{\mathrm{f}}\right)$ for bulk $\mathrm{Cu}-\mathrm{CFT}$ complex in distillate $\mathrm{H}_{2} \mathrm{O}$ at different temperatures.

\begin{tabular}{ccccc}
\hline$T(\mathrm{~K})$ & {$[M]:[L]$} & $\begin{array}{c}\Lambda_{\mathrm{o}} S \\
\mathrm{~cm}^{2} \cdot \mathrm{mol}^{-1}\end{array}$ & $\begin{array}{c}\Lambda_{\mathrm{obs}} S \\
\mathrm{~cm}^{2} \cdot \mathrm{mol}^{-1}\end{array}$ & $\begin{array}{c}\log K_{\mathrm{f}} \\
\mathrm{dm}^{3} \cdot \mathrm{mol}^{-1}\end{array}$ \\
\hline \multirow{2}{*}{288.15} & $1: 2$ & 912.11 & 433.62 & 4.211 \\
& $1: 1$ & 554.03 & 440.05 & 4.424 \\
293.15 & $1: 2$ & 958.50 & 473.22 & 4.186 \\
& $1: 1$ & 584.60 & 331.16 & 4.375 \\
298.15 & $1: 2$ & 966.40 & 465.30 & 4.179 \\
& $1: 1$ & 594.50 & 322.25 & 4.342 \\
303.15 & $1: 2$ & 985.30 & 481.14 & 4.174 \\
& $1: 1$ & 593.40 & 347.49 & 4.275 \\
\hline
\end{tabular}

\section{Biological Activity}

Many transition metals show arresting biological activity, working as active centers within important bioactive molecules in living systems. Copper (II) plays a significant function in cell metabolism and has proved beneficial in numerous diseases [58-60]. Ceftriaxone-metal complexes have both pharmacological and toxicological properties [61]. The interaction between metal ions and ceftriaxone can lead to precipitation resulting in serious adverse drug events [62]. Ceftriaxone complexes have antibacterial properties that can decrease or increase relative to pure ceftriaxone [61]. The antimicrobial activity was estimated based on the size of the inhibition zone formed around discs of bulk $\mathrm{CuCl}_{2} \cdot 2 \mathrm{H}_{2} \mathrm{O}$, nano- $\mathrm{CuCl}_{2} \cdot 2 \mathrm{H}_{2} \mathrm{O}, \mathrm{CFT}$, and its bulk and nano- $\mathrm{Cu}$ complexes on a petri dish with Luria Bertani agar (LB-agar) plates as it measures the compound's efficacy.

4.1. Antibacterial Activity. The antibacterial activities of bulk $\mathrm{CuCl}_{2} \cdot 2 \mathrm{H}_{2} \mathrm{O}$, nano- $\mathrm{CuCl}_{2} \cdot 2 \mathrm{H}_{2} \mathrm{O}$, bulk and nano-Cu-CFT complexes were compared with the activity of CFT and as presented in Table 11. Bulk $\mathrm{CuCl}_{2} \cdot 2 \mathrm{H}_{2} \mathrm{O}$ provides an excellent
TABLE 8: Limiting molar conductance $\left(\Lambda_{\mathrm{o}}\right)$ and formation constant $\left(K_{\mathrm{f}}\right)$ for nano-Cu-CFT complex in distillate $\mathrm{H}_{2} \mathrm{O}$ at different temperatures.

\begin{tabular}{ccccc}
\hline$T(\mathrm{~K})$ & {$[M]:[L]$} & $\Lambda_{\mathrm{o}} S \mathrm{~cm}^{2} \cdot \mathrm{mol}^{-1}$ & $\begin{array}{c}\Lambda_{\mathrm{obs}} S \\
\mathrm{~cm}^{2} \cdot \mathrm{mol}^{-1}\end{array}$ & $\begin{array}{c}\mathrm{Log} K_{\mathrm{f}} \\
\mathrm{dm}^{3} \cdot \mathrm{mol}^{-1}\end{array}$ \\
\hline \multirow{2}{*}{288.15} & $1: 2$ & 912.00 & 439.56 & 4.191 \\
& $1: 1$ & 555.00 & 290.00 & 4.426 \\
293.15 & $1: 2$ & 966.00 & 473.22 & 4.177 \\
& $1: 1$ & 593.00 & 331.16 & 4.349 \\
298.15 & $1: 2$ & 958.00 & 485.10 & 4.180 \\
& $1: 1$ & 584.00 & 335.61 & 4.323 \\
303.15 & $1: 2$ & 985.30 & 481.14 & 4.171 \\
& $1: 1$ & 593.00 & 348.98 & 4.263 \\
\hline
\end{tabular}

antimicrobial activity, and such property is greatly improved when using nano- $\mathrm{CuCl}_{2} \cdot 2 \mathrm{H}_{2} \mathrm{O}$. It was observed also that CFT has a higher zone of inhibition than bulk and nano-Cu-CFT complexes in Klebsiella pneumonia and Pseudomonas aeruginosa (gram-negative bacteria), Figure 11.

The antibacterial activity of Cu-CFT complexes depends on the bacterial species. The complexes and antibiotics presented inhibition zones of diameters larger than $20 \mathrm{~mm}$ showing that they have good activity as bactericides [63]. The antibacterial effect against Staphylococcus aureus is present at the bulk and nano-Cu-CFT complexes (the inhibition zones are 21 and $16 \mathrm{~mm}$, respectively). These values are lower than the corresponding values for bulk $\mathrm{CuCl}_{2} \cdot 2 \mathrm{H}_{2} \mathrm{O}$ and nano- $\mathrm{CuCl}_{2} \cdot 2 \mathrm{H}_{2} \mathrm{O}$ and ceftriaxone. The data indicate that ceftriaxone ligand is more active than their metal complexes; this may be because the chelating ligands containing $\mathrm{N}$ and $\mathrm{O}$ donor atoms show wide biological activity through bonding to metal ions $[64,65]$. However, the synergetic effects of ceftriaxone and $\mathrm{Cu}$ ion may play an important function in the inhibition of bacterial growth after the complex decomposition. These effects are due to the different mechanisms of the action of antibiotics and heavy ions on the bacteria metabolism $[66,67]$. 


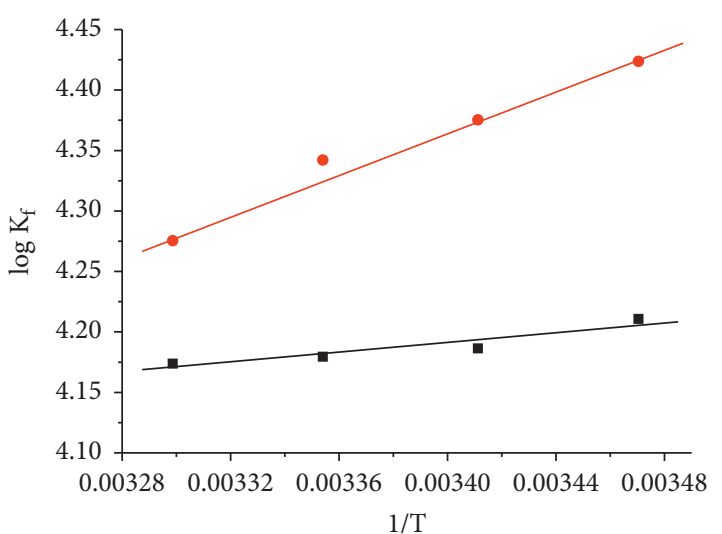

- 1:2 M:L

- 1:1 M:L

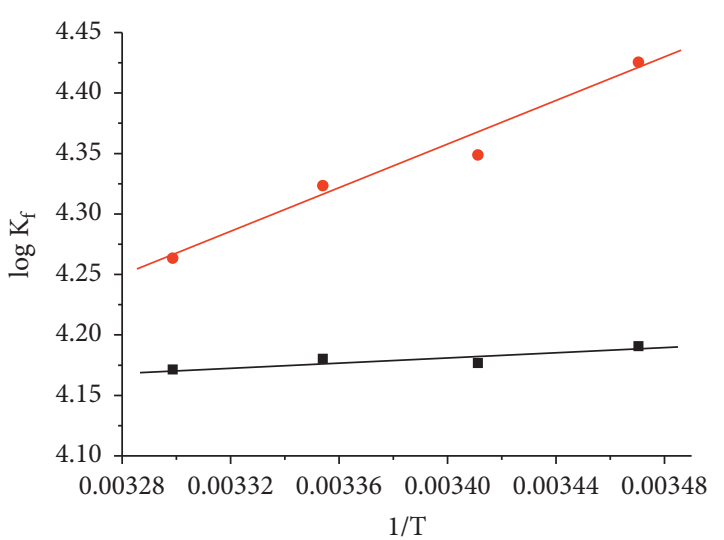

- 1:2 M:L

- 1:1 M:L

(a)

(b)

Figure 10: Variation of $\log K_{\mathrm{f}}$ with $\mathrm{l} / \mathrm{T}$ for (a) bulk Cu-CFT complex and (b) nano-Cu-CFT complex in distillate $\mathrm{H}_{2} \mathrm{O}$.

TABLE 9: Different formation parameters (Gibbs free energy of formation $\left(\Delta G_{\mathrm{f}}\right)$, enthalpy change $\left(\Delta H_{\mathrm{f}}\right)$, and entropy change $\left.\left(\Delta S_{\mathrm{f}}\right)\right)$ for bulk $\mathrm{Cu}$-CFT complex in distillate $\mathrm{H}_{2} \mathrm{O}$ at different temperatures.

\begin{tabular}{|c|c|c|c|c|}
\hline$T(\mathrm{~K})$ & Complex ratio $(M: L)$ & $\Delta G_{\mathrm{f}}\left(\mathrm{kJ} \mathrm{\textrm {mol } ^ { - 1 } )}\right.$ & $\Delta H_{\mathrm{f}}\left(\mathrm{kJ} \mathrm{mol}{ }^{-1}\right)$ & $\Delta S_{\mathrm{f}}\left(\mathrm{kJ} \mathrm{mol} \mathrm{m}^{-1} \mathrm{~K}^{-1}\right)$ \\
\hline 288.15 & & -23.23 & & 0.0252 \\
\hline 293.15 & & -23.50 & & 0.0257 \\
\hline 298.15 & $(1: 2)$ & -23.86 & -3.97 & 0.0265 \\
\hline 303.15 & & -24.23 & & 0.0273 \\
\hline 288.15 & & -24.41 & & 0.0847 \\
\hline 293.15 & & -24.56 & & 0.0838 \\
\hline 298.15 & $(1: 1)$ & -24.79 & -15.96 & 0.0831 \\
\hline 303.15 & & -24.82 & & 0.0819 \\
\hline
\end{tabular}

TABLE 10: Different formation parameters (Gibbs free energy of formation $\left(\Delta G_{\mathrm{f}}\right)$, enthalpy change $\left(\Delta H_{\mathrm{f}}\right)$, and entropy change $\left.\left(\Delta S_{\mathrm{f}}\right)\right)$ for nano-Cu-CFT complex in distillate $\mathrm{H}_{2} \mathrm{O}$ at different temperatures.

\begin{tabular}{|c|c|c|c|c|}
\hline$T(\mathrm{~K})$ & Complex ratio $(M: L)$ & $\Delta G_{\mathrm{f}}\left(\mathrm{kJ} \mathrm{mol}{ }^{-1}\right)$ & $\Delta H_{\mathrm{f}}\left(\mathrm{kJ} \mathrm{mol}{ }^{-1}\right)$ & $\Delta S_{\mathrm{f}}\left(\mathrm{kJ} \mathrm{mol} \mathrm{m}^{-1} \mathrm{~K}^{-1}\right)$ \\
\hline 288.15 & \multirow{4}{*}{$(1: 2)$} & -23.12 & \multirow{4}{*}{-1.82} & 0.0208 \\
\hline 293.15 & & -23.44 & & 0.0215 \\
\hline 298.15 & & -23.86 & & 0.0226 \\
\hline 303.15 & & -24.21 & & 0.0234 \\
\hline 288.15 & \multirow{4}{*}{$(1: 1)$} & -24.42 & \multirow{4}{*}{-17.13} & 0.0847 \\
\hline 293.15 & & -24.41 & & 0.0833 \\
\hline 298.15 & & 24.68 & & 0.0828 \\
\hline 303.15 & & -24.75 & & 0.0816 \\
\hline
\end{tabular}

TABLE 11: Inhibition zones for antibacterial activity (gram-negative bacteria) and antifungal activity (Candida albicans).

\begin{tabular}{|c|c|c|c|}
\hline \multirow{3}{*}{ Compound } & \multicolumn{3}{|c|}{ Inhibition zone (mm) } \\
\hline & \multicolumn{2}{|c|}{ Types of gram-negative bacteria } & \multirow{2}{*}{$\begin{array}{c}\text { Type of fungi } \\
\text { Candida albicans }\end{array}$} \\
\hline & Klebsiella pneumonia & Staphylococcus aureus & \\
\hline Bulk $\mathrm{CuCl}_{2} \cdot 2 \mathrm{H}_{2} \mathrm{O}$ & 19 & 17 & 12 \\
\hline Nano- $\mathrm{CuCl}_{2} \cdot 2 \mathrm{H}_{2} \mathrm{O}$ & 23 & 22 & 14 \\
\hline Ceftriaxone (CFT) & 34 & 33 & 0 \\
\hline Bulk Cu-CFT complex & 24 & 21 & 8 \\
\hline Nano-Cu-CFT complex & 25 & 16 & 9 \\
\hline
\end{tabular}




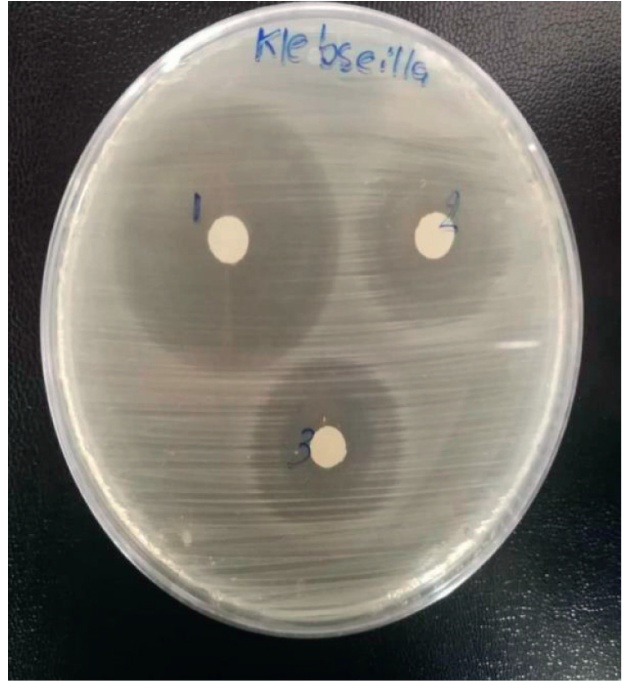

(a)

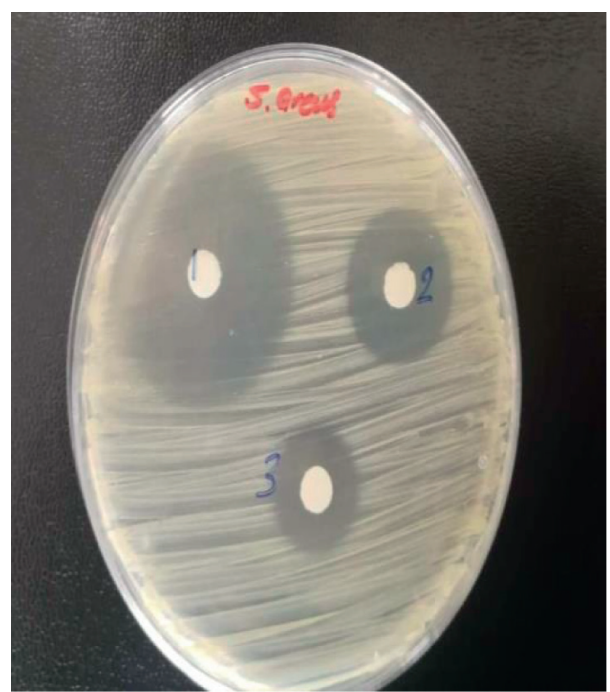

(b)

Figure 11: Inhibition zone around the discs $(6 \mathrm{~mm})$ containing (1) CFT, (2) bulk Cu-CFT complex, and (3) nano-Cu-CFT complex placed on the surface of an LB-agar plate with (a) Klebsiella pneumonia and (b) Pseudomonas aeruginosa.

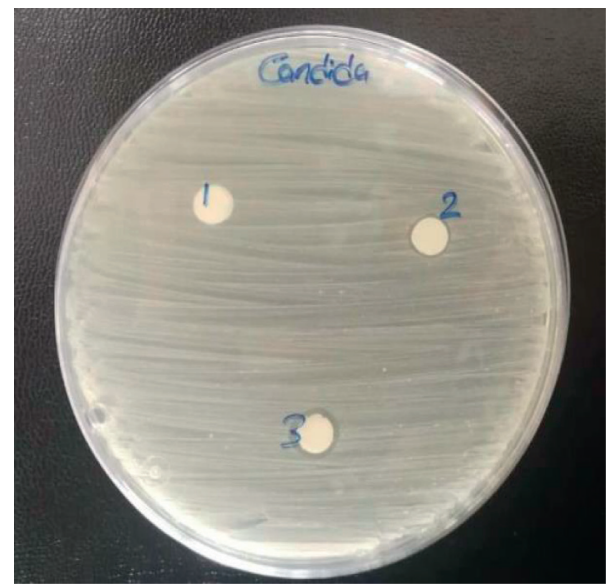

FIgURE 12: Inhibition zone around the discs $(6 \mathrm{~mm})$ containing (1) CFT, (2) bulk Cu-CFT complex, and (3) nano-Cu-CFT complex placed on the surface of an LB-agar plate with Candida albicans .

4.2. Antifungal Activity. The experimental antifungal activity data are presented in Table 11 which indicates that the nano-Cu-CFT complex showed a higher clear zone of inhibition against Candida albicans compared to the bulk $\mathrm{Cu}$-CFT complex while there was an absence of the inhibition zone in CFT. So, the nano-Cu-CFT complex can be used as an antifungal drug, as shown in Figure 12. The zone of inhibition after treatment with bulk and nano$\mathrm{Cu}$-CFT complex was 8 and $9 \mathrm{~mm}$, respectively. According to the standard criteria for evaluation of the drugs, the antifungal action such as a small zone of inhibition indicates that Candida albicans is stable with respect to CFT. The inhibition zones were completely absent, indicating the resistance of these fungi to CFT as well.

\section{Conclusion}

The nano- $\mathrm{CuCl}_{2} \cdot 2 \mathrm{H}_{2} \mathrm{O}$ salt was prepared by ball milling method. The thermodynamic association parameters of both bulk and nano- $\mathrm{CuCl}_{2} \cdot 2 \mathrm{H}_{2} \mathrm{O}$ salts in $\mathrm{H}_{2} \mathrm{O}$ were calculated using the conductometric method by applying the FuossShedlovsky method at different temperatures. It shows that the association parameters of nano- $\mathrm{CuCl}_{2} \cdot 2 \mathrm{H}_{2} \mathrm{O}$ are greater than bulk $\mathrm{CuCl}_{2} \cdot 2 \mathrm{H}_{2} \mathrm{O}$ salt due to the high surface-to-volume ratio of the nanoparticles which leads to a greater ability for ion-pair formation.

The thermodynamic parameters of complexation between bulk and nano- $\mathrm{CuCl}_{2} \cdot 2 \mathrm{H}_{2} \mathrm{O}$ salts and ceftriaxone antibiotic in $\mathrm{H}_{2} \mathrm{O}$ were calculated from conductance measurement. It was found that the formation of Gibbs free 
energies change $\left(\Delta G_{f}\right)$ was decreased in negative signs with increasing temperatures. Two stoichiometric complexes, $1 / 2$ and $1 / 1(M / L)$, are formed with the formation constant and Gibbs free energy of the formed complexes following the order $K_{\mathrm{f}}(1: 1)>K_{\mathrm{f}}(1: 2)$ for $(\mathrm{M}: \mathrm{L})$ and $\Delta G_{\mathrm{f}}(1: 1)>\Delta G_{\mathrm{f}}(1:$ 2) for $(M: L)$ (in negative values) indicates the favorable of formation of $(1: 1)$ complex compared to $(1: 2)$ complex. Also, there is a decrease in values of $K_{\mathrm{f}}$ and $\Delta G_{\mathrm{f}}$ in case of using nano- $\mathrm{CuCl}_{2} \cdot 2 \mathrm{H}_{2} \mathrm{O}$ compared to using bulk $\mathrm{CuCl}_{2} \cdot 2 \mathrm{H}_{2} \mathrm{O}$ but in small difference due to the more solvation effect in case of using nanoparticles.

It was observed that CFT has a higher zone of inhibition and antibacterial activity than that of bulk and nano- $\mathrm{Cu}-$ CFT complexes in Klebsiella pneumonia and Pseudomonas aeruginosa (gram-negative bacteria). The nano-Cu-CFT complex showed a higher clear zone of inhibition and antifungal activity against candida compared to the bulk $\mathrm{Cu}$ CFT complex while there was an absence of the inhibition zone in CFT, so the nano-Cu-CFT complex can be used as an antifungal drug.

\section{Data Availability}

The data are available on request from the corresponding author.

\section{Conflicts of Interest}

The authors declare that there are no conflicts of interest regarding the publication of this paper.

\section{Authors' Contributions}

Elsayed M. AbouElleef conceptualized the study, supervised the study, wrote the original draft, reviewed and edited the article, developed the methodology, performed formal Analysis, performed data collection and analysis, performed investigation, performed visualization, and performed project administration. Mowafak M. Mahrouka performed investigation, developed the methodology, and wrote the manuscript. Sherine E. Salem performed data collection and analysis, provided the resources, performed investigation, and developed the methodology.

\section{Acknowledgments}

The authors gratefully acknowledge the approval and the support of this research study by from the Deanship of Scientific Research at Northern Border University Grant no. 8022-SAR-2018-3-9-F, Arar, KSA.

\section{References}

[1] J. D. Moore, J. P. Stegemeier, K. Bibby, S. M. Marinakos, G. V. Lowry, and K. B. Gregory, "Impacts of pristine and transformed $\mathrm{Ag}$ and $\mathrm{Cu}$ engineered nanomaterials on surficial sediment microbial communities appear short-lived," Environmental Science and Technology, vol. 50, no. 5, pp. 26412651, 2016.

[2] S. D. Nishu, S. Park, Y. Ji, I. Han, J. Key, and T. K. Lee, "The effect of engineered PLGA nanoparticles on nitrifying bacteria in the soil environment," Journal of Industrial and Engineering Chemistry, vol. 84, pp. 297-304, 2020.

[3] V. D. Chavada, N. M. Bhatt, M. Sanyal, and P. S. Shrivastav, "Citrate/melamine functionalized gold nanoparticles for concurrent determination of allopurinol and its major metabolite, oxypurinol in plasma and pharmaceuticals," Journal of Industrial and Engineering Chemistry, vol. 84, pp. 141-149, 2020.

[4] L. Narimani, M. Rezayi, W. P. Meng, and Y. Alias, "Measurements of thermodynamic parameters for complexation between a tetra-aza macrocycle ligand and some metal cations based on conductometric method," Measurement, vol. 77, pp. 362-372, 2016.

[5] J. N. Tiwari, R. N. Tiwari, and K. S. Kim, "Zero-dimensional, one-dimensional, two-dimensional and three-dimensional nanostructured materials for advanced electrochemical energy devices," Progress in Materials Science, vol. 57, no. 4, pp. 724-803, 2012.

[6] J. E. Lee, N. Lee, T. Kim, J. Kim, and T. Hyeon, "Multifunctional mesoporous silica nanocomposite nanoparticles for theranostic applications," Accounts of Chemical Research, vol. 44, no. 10, pp. 893-902, 2011.

[7] H. Barrak, T. Saied, P. Chevallier, G. Laroche, A. M'nif, and A. H. Hamzaoui, "Synthesis, characterization, and functionalization of $\mathrm{ZnO}$ nanoparticles by $\mathrm{N}$-(trimethoxysilylpropyl) ethylenediamine triacetic acid (TMSEDTA): investigation of the interactions between phloroglucinol and ZnO@TMSEDTA," Arabian Journal of Chemistry, vol. 12, no. 8, pp. 4340-4347, 2019.

[8] M. Mansha, A. Qurashi, N. Ullah, F. O. Bakare, I. Khan, and Z. H. Yamani, "Synthesis of In2O3/graphene heterostructure and their hydrogen gas sensing properties," Ceramics International, vol. 42, no. 9, pp. 11490-11495, 2016.

[9] I. Rawal and A. Kaur, "Synthesis of mesoporous polypyrrole nanowires/nanoparticles for ammonia gas sensing application," Sensors and Actuators A: Physical, vol. 203, pp. 92-102, 2013.

[10] H. Ullah, I. Khan, Z. H. Yamani, and A. Qurashi, "Sonochemical-driven ultrafast facile synthesis of $\mathrm{SnO} 2$ nanoparticles: growth mechanism structural electrical and hydrogen gas sensing properties," Ultrasonics Sonochemistry, vol. 34, pp. 484-490, 2017.

[11] M. Ganesh, P. Hemalatha, M. M. Peng, and H. T. Jang, "One pot synthesized $\mathrm{Li}, \mathrm{Zr}$ doped porous silica nanoparticle for low temperature $\mathrm{CO}_{2}$ adsorption," Arabian Journal of Chemistry, vol. 10, pp. S1501-S1505, 2017.

[12] P. V. R. K. Ramacharyulu, R. Muhammad, J. Praveen Kumar, G. K. Prasad, and P. Mohanty, "Iron phthalocyanine modified mesoporous titania nanoparticles for photocatalytic activity and CO2 capture applications," Physical Chemistry Chemical Physics, vol. 17, no. 39, pp. 26456-26462, 2015.

[13] M. Shaalan, M. Saleh, M. El-Mahdy, and M. El-Matbouli, "Recent progress in applications of nanoparticles in fish medicine: a review," Nanomedicine: Nanotechnology, Biology and Medicine, vol. 12, no. 3, pp. 701-710, 2016.

[14] A. Astefanei, O. Núñez, and M. T. Galceran, "Characterisation and determination of fullerenes: a critical review," Analytica Chimica Acta, vol. 882, pp. 1-21, 2015.

[15] K. Saeed and I. Khan, "Preparation and characterization of single-walled carbon nanotube/nylon 6, 6 nanocomposites," Instrumentation Science \& Technology, vol. 44, no. 4, pp. 435-444, 2016.

[16] K. Saeed and I. Khan, "Preparation and properties of singlewalled carbon nanotubes/poly(butylene terephthalate) 
nanocomposites," Iranian Polymer Journal (English Edition), vol. 23, no. 1, pp. 53-58, 2014.

[17] J. M. Ngoy, N. Wagner, L. Riboldi, and O. Bolland, “A CO2 capture technology using multi-walled carbon nanotubes with polyaspartamide surfactant," Energy Procedia, vol. 63, pp. 2230-2248, 2014.

[18] P. G. Tratnyek and R. L. Johnson, "Nanotechnologies for environmental cleanup," Nano Today, vol. 1, no. 2, pp. 44-48, 2006.

[19] N. C. Mueller and B. Nowack, "Exposure modeling of engineered nanoparticles in the environment," Environmental Science and Technology, vol. 42, no. 12, pp. 4447-4453, 2008.

[20] E. C. Dreaden, A. M. Alkilany, X. Huang, C. J. Murphy, and M. A. El-Sayed, "The golden age: gold nanoparticles for biomedicine," Chemical Society Reviews, vol. 41, no. 7, pp. 2740-2779, 2012.

[21] E. T. Helmy, E. M. Abouellef, U. A. Soliman, and J. H. Pan, "Novel green synthesis of S-doped TiO2 nanoparticles using Malva parviflora plant extract and their photocatalytic, antimicrobial and antioxidant activities under sunlight illumination," Chemosphere, vol. 271, Article ID 129524, 2021.

[22] S. Alemayehu, T. Admasu, F. Mamo et al., "Evaluation of ceftriaxone utilization in medical and emergency wards of TikurAnbessa specialized hospital: a prospective cross sectional study," BMC Pharmacology, vol. 17, p. 7, 2016.

[23] F. A. Abebe, D. F. Berhe, A. H. Berhe et al., "Drug use evaluation of ceftriaxone: the case of ayder referral hospital, mekelle, Ethiopia," International Journal of Pharmaceutical Sciences and Research, vol. 3, pp. 2191-2195, 2012.

[24] E. Hedlund, "The protective effects of beta-lactam antibiotics in motor neuron disorders," Experimental Neurology, vol. 231, no. 1, pp. 14-18, 2011.

[25] D. A. Raja, S. G. Musharraf, M. R. Shah, A. Jabbar, and M. I. Bhanger, "Poly(propylene glycol) stabilized gold nanoparticles: an efficient colorimetric assay for ceftriaxone," Journal of Industrial and Engineering Chemistry, 2020.

[26] E. M. AbouElleef, M. N. Abd El-Hady, E. A. Gomaa, and A. G. Al-Harazie, "Conductometric association parameters for $\mathrm{CdBr} 2$ in the presence and absence of Ceftazidime in water and 30\% ethanol-water mixtures," Journal of Chemical \& Engineering Data, vol. 66, no. 2, pp. 878-889, 2021.

[27] E. M. AbouElleef and S. D. Mekkey, "Study of the thermodynamic parameters for interaction of ciprofloxacin antibiotic with bulk and nanocopper sulfate," Journal of Biochemical Technology, vol. 10, no. 1, pp. 57-66, 2019.

[28] G. H. Rounaghi, M. Mohajeri, S. Ahmadzadeh, and S. Tarahomi, "A thermodynamic study of interaction of $\mathrm{Na}+$ cation with benzo-15-crown-5 in binary mixed non-aqueous solvents," Journal of Inclusion Phenomena and Macrocyclic Chemistry, vol. 63, no. 3-4, pp. 365-372, 2009.

[29] S. Ahmadzadeh, M. Rezayi, E. Faghih-Mirzaei, M. Yoosefian, and A. Kassim, "Highly selective detection of titanium (III) in industrial waste water samples using meso-octamethylcalix[4] pyrrole-doped PVC membrane ion-selective electrode," Electrochimica Acta, vol. 178, pp. 580-589, 2015.

[30] S. Ahmadzadeh, M. Rezayi, H. Karimi-Maleh, and Y. Alias, "Conductometric measurements of complexation study between 4-Isopropylcalix[4]arene and Cr3+ cation in THFDMSO binary solvents," Measurement, vol. 70, pp. 214-224, 2015.

[31] S. Ahmadzadeh, M. Yoosefian, and M. Rezayi, "Comprehensive experimental and theoretical investigations on chromium (III) trace detection in biological and environmental samples using polymeric membrane sensor,"
International Journal of Environmental Analytical Chemistry, pp. 1-16, 2019.

[32] S. Badakhshan, S. Ahmadzadeh, A. Mohseni-Bandpei, M. Aghasi, and A. Basiri, "Potentiometric sensor for iron (III) quantitative determination: experimental and computational approaches," BMC Chemistry, vol. 13, no. 1, p. 131, 2019.

[33] S. Santra and B. Das, "Counterion-binding and related phenomena in sodium alginate-sodium chloride-water ternary systems: a conductometric study," Journal of Molecular Liquids, vol. 296, p. 111930, 2019.

[34] P. Scherrer, Nachrichten von der Gesellschaft der Wissenschaften zu Gittingen, Mathematisch-Physikalische Klasse, vol. 26, no. 1, pp. 98-100, Jul. 1918.

[35] Y. Waseda, E. Matsubara, and K. Shinoda, X-ray Diffraction Crystallography: Introduction, Examples and Solved Problems, Springer, Berlin, Germany, 2011.

[36] D. Harker, "The crystal structure of cupric chloride dihydrate $\mathrm{CuCl}_{2} \cdot 2 \mathrm{H}_{2} \mathrm{O}$," Zeitschrift für Kristallographie - Crystalline Materials, vol. 93, no. 1-6, pp. 136-145, 1936.

[37] A. Umer, S. Naveed, N. Ramzan, M. Rafique, and M. Imran, "A green method for the synthesis of Copper Nanoparticles using L-ascorbic acid," Matéria (Rio de Janeiro), vol. 19, no. 3 , pp. 197-203, 2014.

[38] R. A. Nyquist, “ $\alpha$-Halo- $p$-X-substituted acetanilides: effects on the $\mathrm{N}-\mathrm{H}$ and $\mathrm{C}=\mathrm{O}$ stretching frequencies and intensities in dilute solution," Spectrochimica Acta, vol. 19, no. 9, pp. 1595-1605, 1963.

[39] M. Mashima, "Infrared absorption spectra of hydrazides. I. Hydrazides of aromatic acidsp," Bulletin of the Chemical Society of Japan, vol. 35, no. 332, p. 1862, 1962.

[40] H. J. Bernstein, "The average XH stretching frequency as a measure of XH bond properties," Spectrochimica Acta, vol. 18, no. 2, pp. 161-170, 1962.

[41] A. Marco, Compt. Rend.vol. 274B, p. 400, 1972.

[42] A. Tramer, " $\mathrm{N}^{\circ} 25$. - spectres de vibration et structure des sulfocyanures complexes," Journal de Chimie Physique, vol. 59, pp. 232-240, 1962.

[43] J. Chouteau, G. Davidovics, J. Metzger, and A. Bonzom, "Sur le spectre infrarouge de l'amino-2 thiazole, du méthyl-4 amino-2 thiazole et de leurs dérivés NN dialcoylés-II," Etude á l'état liquide-Essai d'interprétation générale.cccSpectrochimica Acta, vol. 22, no. 4, pp. 719-735, 1966.

[44] M. Oki and M. Hirota, "Intramolecular hydrogen bonding in $\alpha$-keto-and $\alpha$-alkoxy-carboxylic acids. VI. substituent effects on the energy of the hydrogen bonding in a-alkoxy-and a-alkoxy-and a-aryloxyacetic acids," Bulletin of the Chemical Society of Japan, vol. 36, p. 290, 1963.

[45] A. S. Gilbert, A. M. North, T. G. Parker, and R. A. Pethrick, "Submillimetre and far i.r. studies of normal and branched chain hydrocarbons," Spectrochimica Acta Part A: Molecular Spectroscopy, vol. 32, no. 5, pp. 931-936, 1976.

[46] A. J. Abdulghani and S. K. Mohuee, "Synthesis and characterization of new schiff bases derived from ceftriaxone sodium with $1 \mathrm{H}$ - indole-2, 3- dione (isatin) and 1-acetyl indoline-2, 3dione (NAcetylisatin) and their platinum (IV) complexes," Journal of Chemical, Biological and Physical Sciences, vol. 6, pp. 579-595, 2016.

[47] A. J. Abdulghani and R. K. Hussain, "Synthesis and characterization of schiff base metal complexes derived from cefotaxime with $1 \mathrm{H}$-indole-2,3-dione (isatin) and 4-N,N-dimethyl-aminobenzaldehyde," Open Journal of Inorganic Chemistry, vol. 05, no. 04, pp. 83-101, 2015.

[48] E. A. Gomaa, E. M. AbouElleef, K. S. Shalaby, and S. E. Salem, "Thermodynamic effect of bulk and nano-CuCl2 salts on 
tenoxicam using a variety of different techniques," Journal of Forestry and Environment, vol. 1, pp. 44-53, 2014.

[49] E. T. Helmy, E. A. Gomaa, and E. M. AbouElleef, "Complexation of 2-mercaptoimidazol with some barium salts conductometrically in various solvents at different temperatures," Int. J. Mod. Chem.vol. 7, pp. 141-155, 2015.

[50] G. Kumar and M. S. Chauhan, "Conductometric investigations of surfactant behavior in aqueous polar aprotic organic additives," Journal of Molecular Liquids, vol. 249, pp. 710-715, 2018.

[51] A. A. Khan, M. Q. Khan, and R. Hussain, "Determination of $\mathrm{Cu} 2+$ in aqueous solution using a polyindole-tin(IV) molybdophosphate conductive nanocomposite ion-selective membrane electrode," Journal of Physics and Chemistry of Solids, vol. 123, pp. 113-123, 2018.

[52] S. Das, D. Ekka, and M. Roy, "Conductance and FTIR spectroscopic study of triple-ion formation of tetrabutylphosphonium methanesulfonate in methylamine solution," Chemical Methodologies, vol. 4, no. 1, pp. 55-67, 2020.

[53] E. A. Gomaa, E. M. AbouElleef, and E. T. Helmy, "Conductance studies on complex formation between $\mathrm{CaCl} 2$ and ampicillin as ligand in water and in methanol solvent at different temperatures," RRJPPS, vol. 3, pp. 55-64, 2014.

[54] E. A Gomaa and R. Tarek Rashad, "Determination of thermodynamic parameters of VOSO4 in different organic mixed solvents," Chemical Sciences Journal, vol. 09, no. 02, p. 187, 2018.

[55] E. AbouElleef and E. Helmy, "Antibiotic oxytetracycline solvation Inter.ctions with ethanol-aqueous mixturs at different temperatures," Egyptian Journal of Chemistry, vol. 63, no. 2, pp. 499-506, 2020.

[56] E. A. Gomaa, A. Negm, and M. A. Tahoon, "Conductometric and volumetric study of copper sulphate in aqueous ethanol solutions at different temperatures," Journal of Taibah University for Science, vol. 11, no. 5, pp. 741-748, 2017.

[57] M. Biedulska, A. Chylewska, and D. Nidzworski, "Comparative solution equilibria studies of complex formation between $\operatorname{Ir}(\mathrm{III})$ ion and antituberculosis drug analogues: spectroscopic, potentiometric and conductometric approach," Journal of Molecular Liquids, vol. 296, Article ID 111887, 2019.

[58] D. R. Williams, The Metals of Life, Van Nostrand Reinhold, London, 1971.

[59] D. H. Brown, W. E. Smith, J. W. Teape, and A. J. Lewis, "Antiinflammatory effects of some copper complexes," Journal of Medicinal Chemistry, vol. 23, no. 7, pp. 729-734, 1980.

[60] J. R. J. Sorenson, Copper in the EnvironmentWiley-Interscience, New York, NY, USA, 1981.

[61] J. R. Anacona and A. Rodriguez, "Synthesis and antibacterial activity of ceftriaxone metal complexes," Transition Metal Chemistry, vol. 30, no. 7, pp. 897-901, 2005.

[62] H.-R. Schmutz, P. Detampel, T. Bühler, A. Büttler, B. Gygax, and J. Huwyler, "In vitro assessment of the formation of ceftriaxone-calcium precipitates in human plasma," Journal of Pharmaceutical Sciences, vol. 100, no. 6, pp. 2300-2310, 2011.

[63] D. L. Shungu, E. Weinberg, and H. H. Gadebusch, “Tentative interpretive standards for disk diffusion susceptibility testing with norfloxacin (MK-0366, AM-715)," Antimicrobial Agents and Chemotherapy, vol. 23, no. 2, pp. 256-260, 1983.

[64] R. C. Maurya, P. Patel, and S. Rajput, "Synthesis and characterization of $\mathrm{N}$-(o-Vanillinidene)-p-anisidine and $\mathrm{N}, \mathrm{N}^{\prime}$-bis(o-Vanillinidene)ethylenediamine and their metal complexes," Synthesis and Reactivity in Inorganic and MetalOrganic Chemistry, vol. 33, no. 5, pp. 817-836, 2003.

[65] U. Bohme and B. Gunther, Inorganic Chemistry Communications, vol. 10, pp. 482-484, 2007.

[66] L. Peng, R. Lifang, X. Hongyu, L. Xi, and Z. Chaocan, "Study on the toxic effect of lead(II) ion on Escherichia coli," Biological Trace Element Research, vol. 115, no. 2, pp. 195-202, 2007.

[67] A. Yotsuji, J. Mitsuyama, R. Hori et al., "Outer membrane permeation of Bacteroides fragilis by cephalosporins," Antimicrobial Agents and Chemotherapy, vol. 32, no. 7, pp. 1097-1099, 1988. 